Portland State University

PDXScholar

4-7-2021

\title{
Glaciers of the Olympic Mountains, Washington - The Past and Future 100 Years
}

\author{
Andrew G. Fountain \\ Portland State University, andrew@pdx.edu \\ Christina Gray \\ Portland State University \\ Bryce Allen Glenn \\ Portland State University, bryce.a.glenn@gmail.com \\ Brian Menounos \\ University of Northern British Columbia \\ Justin Pflug \\ University of Northern British Columbia
}

See next page for additional authors

Follow this and additional works at: https://pdxscholar.library.pdx.edu/geology_fac

Part of the Geology Commons

Let us know how access to this document benefits you.

\section{Citation Details}

Published as: Fountain, A. G., Gray, C., Glenn, B., Menounos, B., Pflug, J., \& Riedel, J. L. (2022). Glaciers of the Olympic Mountains, Washington-The past and future 100 years. Journal of Geophysical Research: Earth Surface, 127, e2022JF006670. https://doi.org/10.1029/2022JF006670

This Post-Print is brought to you for free and open access. It has been accepted for inclusion in Geology Faculty Publications and Presentations by an authorized administrator of PDXScholar. Please contact us if we can make this document more accessible: pdxscholar@pdx.edu. 
Authors

Andrew G. Fountain, Christina Gray, Bryce Allen Glenn, Brian Menounos, Justin Pflug, and Jon L. Riedel

This post-print is available at PDXScholar: https://pdxscholar.library.pdx.edu/geology_fac/191 


\section{Andrew G. Fountain ${ }^{1}$, Christina Gray ${ }^{1}$, Bryce Glenn ${ }^{1}$, Brian Menounos ${ }^{2}$, Justin Pflug ${ }^{2}$ Jon L.} Riedel $^{3}$

${ }^{1}$ Department of Geology, Portland State University, Portland, Oregon, USA

${ }^{2}$ Geography Program, University of Northern British Columbia, 3333 University Way, Prince George, British Columbia Canada

${ }^{3}$ Department of Civil and Environmental Engineering, University of Washington, Seattle, Washington, USA

${ }^{4}$ US National Park Service, North Cascades National Park, 810 State Route 20, Sedro-Woolley, Washington USA

Key Points:

- The glaciers of the Olympus Peninsula are shrinking rapidly, losing half of its ice-

23

- Warming air temperatures are causing glacier loss; warming winter temperatures change the phase of the precipitation from snow to rain.

- Modeling suggests the glaciers will largely disappear by 2070

Corresponding author: Andrew G. Fountain, andrew@pdx.edu 
Abstract

In 2015, the Olympic Mountains contain 255 glaciers and perennial snowfields totaling $25.34 \pm$ $0.27 \mathrm{~km}^{2}$, half of the area in 1900, and about $0.75 \pm 0.19 \mathrm{~km}^{3}$ of ice. Since 1980 , glaciers shrank at a rate of $-0.59 \mathrm{~km}^{2} \mathrm{yr}^{-1}$ during which 35 glaciers and 16 perennial snowfields disappeared.

41 Area changes of Blue Glacier, the largest glacier in the study region, was a good proxy for

42 glacier change of the entire region. A simple mass balance model of the glacier, based on

43 monthly air temperature and precipitation, correlates with glacier area change. The mass

44 balance is highly sensitive to changes in air temperature rather than precipitation, typical of

45 maritime glaciers. In addition to increasing summer melt, warmer winter temperatures changed

46 the phase of precipitation from snow to rain, reducing snow accumulation. Changes in glacier

47 mass balance are highly correlated with the Pacific North American index, a proxy for

48 atmospheric circulation patterns and controls air temperatures along the Pacific Coast of North

49 America. Regime shifts of sea surface temperatures in the North Pacific, reflected in the Pacific

50 Decadal Oscillation (PDO), trigger shifts in the trend of glacier mass balance. Negative ('cool')

51 phases of the PDO are associated with glacier stability or slight mass gain whereas positive

52 ('warm') phases are associated with mass loss and glacier retreat. Over the past century the

53 overall retreat is due to warming air temperatures, almost $+1^{\circ} \mathrm{C}$ in winter and $+0.3^{\circ} \mathrm{C}$ in

54 summer. The glaciers in the Olympic Mountains are expected to largely disappear by 2070.

\section{1. Introduction}

59 The Olympic Mountains are the western-most alpine terrain in the Pacific Northwest US, 60 isolated on the Olympic Peninsula of Washington State. These mountains are first to intercept

61 moisture-laden storms originating over the Pacific Ocean with the highest peak (Mt. Olympus)

$6256 \mathrm{~km}$ inland. Although the mountains only reach to $2432 \mathrm{~m}$ above sea level (asl), glaciers

63 mantle the highest mountains due to the heavy winter snowfall and cool summers. 
64 Precipitation varies from $3000 \mathrm{~mm} \mathrm{yr}^{-1}$ on the west side of the range to only $500 \mathrm{~mm} \mathrm{yr}^{-1}$ on the east (Rasmussen et al., 2001).

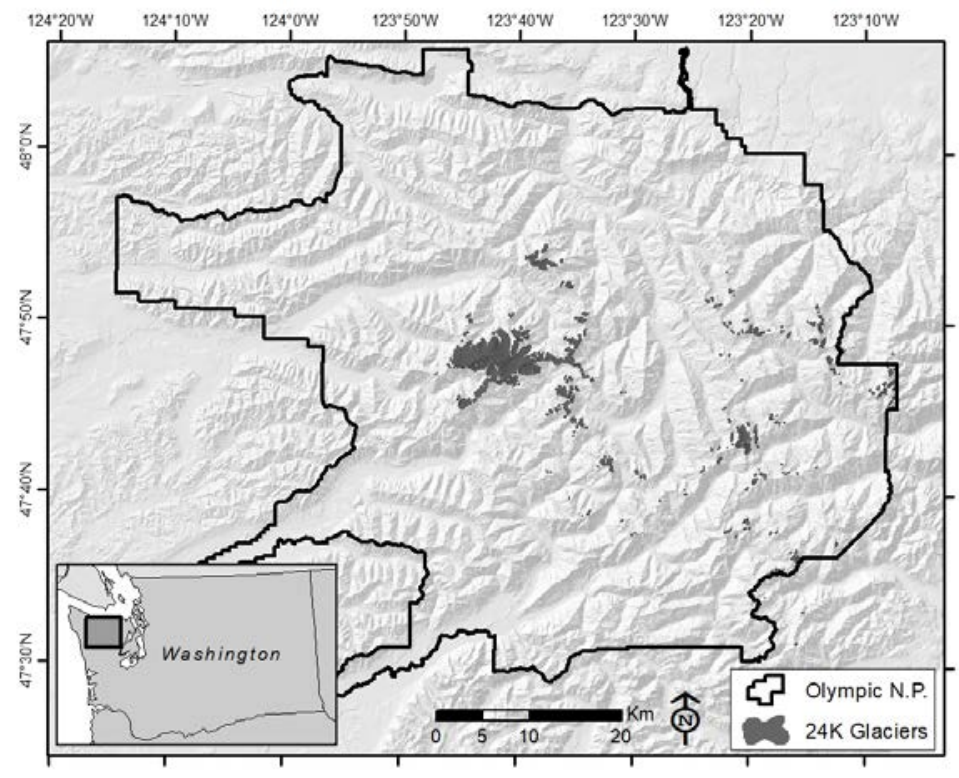

67 Figure 1. Location of the Olympic Peninsula and glaciers. The dark black line is the boundary of

68 Olympic National Park. The gray outlined box surrounds Mt. Olympus.

70 Glaciers were first photographed in 1890 during a US Army Exploring Expedition (Spicer, 1989;

71 Wood, 1976). One glacier, the Blue Glacier, became the focus of interest because it is the

72 largest glacier in the region. During the International Geophysical Year in 1957 it was mapped

73 and identified as one of the glaciers in western North America suitable for monitoring (AGS,

74 1960). In that same year a mass balance monitoring program was established and has

75 continued intermittently (Armstrong, 1989; Conway et al., 1999; LaChapelle, 1959).

76 Spicer (1986) compiled the first detailed inventory of the region. He mapped the glaciers by

77 modifying glacier outlines on US Geological Survey 1:36,360-scale topographic maps according

78 to their extent on vertical aerial photographs $(1: 24,000$ to $1: 60,000)$ acquired in 1976,1979 ,

791981 , and 1982, and supported by field observations from 1980 - 1983. Ice masses were

80 classified as glaciers if they persisted for at least two years; displayed evidence of glacier flow 
81 such as crevasses, medial moraines, meltwater with glacier flour; or showed glacial activity such

82 as terminal or lateral moraines.

84 Fountain et al. (2017) developed a second inventory of glaciers and perennial snowfields in the

85 Olympic Mountains as part of a larger inventory that included the entire western US exclusive 86 of Alaska. The outlines of this newer inventory were abstracted from US Geological Survey

87 1:24,000-scale topographic maps drawn from aerial photography flown in 1943, 1968, 1976,

88 1979, 1985, and 1987. Most glaciers (93\%) were photographed during 1985-1987 and only a

89 few in 1943. This inventory identified more glaciers (391) than Spicer (265) largely due to

90 Spicer's $0.1 \mathrm{~km}^{2}$ area threshold for inclusion, compared to the $0.01 \mathrm{~km}^{2}$ adopted by Fountain et

91 al. (2017). When the $0.1 \mathrm{~km}^{2}$ threshold was applied to Fountain et al. (2017) the distributions of

92 both inventories largely accord. Riedel et al. (2015) compiled a third inventory of glaciers based

93 on aerial photography from 2009. One of the authors (Fountain) was involved with the

94 compilation of this inventory the details of which are summarized in Methods below.

Our objectives are to provide a comprehensive examination of the glaciers in the Olympic

97 Mountains, how they have changed in area and volume since the early 1980 s to 2015 , and how

98 they responded to climatic variations since 1900. This report differs from Riedel et al. (2015) in 99 several ways. First, we provide two new inventories and examine in detail how the populations 100 change over time. We demonstrate that area changes of Blue Glacier are representative of the 101 population as a whole and examine the precipitation and air temperature influences on Blue 102 Glacier in the context of larger climate indices that represent hemispheric scale oceanic and 103 atmospheric processes. Finally, we predict the future of glacier cover in the Olympics over the 104 next century.

105

\section{2. Methods}

107 To assess the changing area and distribution of glaciers in the Olympic Mountains we relied on 108 several previously published glacier inventories and created two new inventories. The first 109 glacier inventory from Spicer (1986) provides the earliest detailed inventory, however, results 
110 are in tabular form with approximate latitude and longitude locations. Newer inventories were

111 compiled in a geographic information system as digital outlines of glaciers and perennial

112 snowfields. Three new inventories were compiled for the Olympic Mountains using vertical

113 aerial photographs flown in September of 1990, 2009, and 2015. The 1990 images are black and

114 white digital orthoquadrangles (DOQs) with a ground resolution of $1 \mathrm{~m}$. They were downloaded

115 from the University of Washington Geomorphological Research Group webpage (UW, 2019).

116 The 2009 and 2015 imagery were obtained from the U.S. Department of Agriculture (USDA)

117 National Agricultural Imagery Program (NAIP) website (USDA, 2019) as $1 \mathrm{~m}$ color georectified

118 orthophotographs. The 2009 inventory was reported in Riedel et al (2015). The 2015 imagery

119 included all but 16 glaciers, which were outlined using WorldView-2 satellite imagery, $0.5 \mathrm{~m}$

120 spatial resolution obtained from Digital Globe and acquired in August and September (Gorelick

121 et al., 2017). The comprehensive inventory of the continental US (Fountain et al., 2007, 2017)

122 was not used because the original USGS imagery of the Olympic Mountains included extensive

123 seasonal snow masking many of the glacier outlines. Also, the imagery dates are within a couple

124 of years of Spicer's inventory rendering the inventory unnecessary.

125

126 The new inventories include both glaciers and perennial snowfields (G\&PS) because they are

127 often hard to distinguish when small and perennial snowfields can be locally important for late

128 summer runoff (Clow \& Sueker, 2000; Elder et al., 1991). Glaciers are identified by the presence

129 of exposed ice and crevasses, indicating a perennial nature and movement, respectively.

130 Snowfields, on the other hand, rarely provide visual clues regarding their perennial nature

131 because their firn core is usually snow-covered in the imagery. We only track their persistent

132 presence in the imagery. Given the episodic nature of suitable imagery over four decades these

133 features cannot be tracked closely. Therefore, we adopt rules from (DeVisser \& Fountain, 2015)

134 to distinguish seasonal from perennial features. In short, if a feature is present in the first

135 inventory (Spicer for glaciers, 1990 for snowfields) and not found in subsequent inventories it is

136 considered seasonal and eliminated. If the feature is found in the first two inventories it is

137 considered perennial, and if it is absent from any subsequent inventory it is considered no

138 longer perennial. Outlines were digitized in ArcGIS (ArcMap, ESRI, Inc) at a scale of 1:2,000 with 
139 vertices spaced at a $5 \mathrm{~m}$ interval. This approach balanced accuracy, productivity, and image 140 resolution. The minimum area threshold was $0.01 \mathrm{~km}^{2}$, consistent with Fountain et al. (2017)

141 for the Western US, and global guidelines for glacier inventories (Paul et al., 2010). To insure 142 internal consistency, the three new inventories were intercompared and any abrupt change in 143 area initiated a reexamination of that G\&PS outline.

145 Area uncertainty results from three sources, positional, digitizing, and interpretation (DeBEER \& 146 Sharp, 2009; DeVisser \& Fountain, 2015). Positional uncertainty $\left(U_{p}\right)$ is the error in the location

147 of the perimeter caused by alignment of the base image during the orthorectification process.

148 Digitizing uncertainty $\left(U_{d}\right)$ results from inaccuracies in following the glacial perimeter during 149 manual digitizing. Finally, interpretation uncertainty $\left(U_{i}\right)$ is the location uncertainty of the 150 glacier margin due to masking by seasonal snow cover, rock debris, or shadows. The total 151 uncertainty $\left(U_{t}\right)$ for each feature is the square root of the sum of the square of each 152 contributing uncertainties (Baird, 1962).

$$
U_{t}=\sqrt{U_{p}^{2}+U_{d}^{2}+U_{i}^{2}}
$$

156 To evaluate (1), we ignored positional uncertainty $\left(U_{p}\right)$ because we are concerned with area not 157 exact location. Furthermore, the digitized points are highly correlated such that they are not 158 independently determined. To evaluate the digitization uncertainty $\left(U_{d}\right)$, we follow (Hoffman et 159 al., 2007) who adapted the method of (Ghilani, 2000). This uncertainty is a product of the 160 length of the side of a square $(S)$ that has the same area as the feature polygon in question 161 multiplied by the linear uncertainty $\left(\sigma_{d}\right)$,

$$
U_{d}=S \sigma_{d} \sqrt{2}
$$

165 To estimate the linear uncertainty $\left(\sigma_{d}\right)$. Ten features of various sizes were digitized at the 166 normal 1:2000 scale and again at 1:500. The linear difference was measured perpendicularly 167 between outlines and the standard deviation calculated. For interpretation uncertainty we tried 
several approaches including, visual estimates (e.g. $5 \%$ of the area is in shadow, uncertainty is

$169 \pm 2.5 \%)$, measured glacier area with and without the questionable subregion using one half of

170 the difference as the uncertainty, or a combination of both approaches where measurements

171 were used to calibrate visual estimates. In most cases we found little difference between

172 methods.

173

174 The uncertainty for snowfields was estimated differently. Snowfield area commonly changed

175 dramatically ( 50\%) between imagery surveys, due to residual seasonal snow. Because its firn

176 core was rarely observed uncertainty is unknown. To document the presence of perennial

177 snowfields but eliminate them from analysis, a large uncertainty was estimated using a buffer

178 around the outline such that the observed changes in area were smaller than the uncertainty.

180 To calculate the topographic characteristics of the initial, (Spicer, 1986) inventory, we used the 181 original National Elevation Dataset based on the 1:24,000 paper maps (Gesch et al., 2002).

182 Most of the mapping (94\%) in the Olympics was based on aerial photography from 1980-1987

183 (Fountain et al., 2017). As will be shown later, during this period little glacier recession occurred 184 and we consider the topography to be representative of the 1980 inventory.

Volume change was estimated by differencing surface elevations of the glaciers collected at

187 different times. Two digital elevation models (DEMs) were used. The earlier DEM is the National

188 Elevation Dataset and the more recent DEM is from aerial lidar collected in summer 2015

189 (Painter et al., 2016). Uncertainty was estimated by the root-mean square error of the elevation differences calculated for the snow-free bedrock adjacent to the glaciers.

192 The local climate of precipitation and maximum/minimum air temperatures was defined using

193 Parameter-elevation Regression on Independent Slopes (PRISM) data (Daly et al., 2007).

194 Monthly values were downloaded at a scale of $4 \mathrm{~km}$ within a box $10.7 \mathrm{~km}$ by $8.5 \mathrm{~km}$, centered 195 over Mt. Olympus $\left(47.7986^{\circ},-123.693^{\circ}\right)($ OSU, 2017). To examine the influence of broader 196 climate patterns climate indices were downloaded from a number of sources. For the Arctic 
197 Oscillation (AO, Barnston and Livezey, 1987; Thompson and Wallace, 1998); Nino 3.4 (Bjerknes,

198 1966; Rayner et al., 2003; Trenberth, 1997); North Atlantic Oscillation (NAO, Jones et al., 1997);

199 North Pacific index (Trenberth \& Hurrell, 1994); Pacific-North American (PNA, Wallace \&

200 Gutzler, 1981), and the Southern Oscillation Index (Cayan, 1996; Chen, 1982; Ropelewski \&

201 Jones, 1987), the data were downloaded from the US National Oceanic and Atmospheric

202 Administration, Earth System Research Laboratory, Physical Sciences Division (NOAA, 2018).

203 The data for the Pacific Decadal Oscillation (PDO, Mantua \& Hare, 2002; Newman et al., 2016),

204 were downloaded from the University of Washington (UW, 2018). The period of correlation was

$2051900-2014$ for all variables except Arctic Oscillation, which was 1950-2014 due to data

206 availability. The correlations reported are for the longer period of record.

207

208 3. Results

209

210 The Spicer (1986) inventory identified 266 glaciers $\geq 0.01 \mathrm{~km}^{2}$, most (94\%) of which were

211 identified from 1979-1982. During this period the glaciers changed little because it coincides

212 with the mid-century cool period when glaciers were either in equilibrium or advancing slightly

213 (Conway et al., 1999; Hodge et al., 1998; Thompson et al., 2010). For simplicity, the inventory is

214 dated to 1980 and referred to as the '1980 inventory'. Our reanalysis revised the 1980

215 inventory to 261 glaciers because one glacier, White Glacier, was counted as two glaciers due to

216 its split terminus into two lobes, and four other features were considered seasonal because

217 they were missing from the following 1990 inventory. Total glacier area was $45.89 \pm 0.51 \mathrm{~km}^{2}$,

218 of which almost half, $20.4 \mathrm{~km}^{2}$, are located on the Olympus Massif. The largest glacier was Blue

219 Glacier, $6.02 \pm 0.30 \mathrm{~km}^{2}$ and the smallest was an unnamed ice mass, $0.01 \mathrm{~km}^{2}$. Average glacier

220 area was $0.18 \mathrm{~km}^{2}$ with a median of $0.05 \mathrm{~km}^{2}$. The area of many glaciers cannot be quantified

221 because Spicer's inventory often grouped small glaciers within the same watershed under a

222 single identification number and summing their area. Mean glacier elevations range from 1319

$223 \mathrm{~m}$ to $2399 \mathrm{~m}$ amsl with a mean elevation of $1726 \mathrm{~m}$. The mean elevation of almost all glaciers

224 (98\%) was < $2000 \mathrm{~m}$ and $45 \%$ have a maximum elevation < $2000 \mathrm{~m}$ (Figure 2). Glaciers facing

225 north $\left(330^{\circ}\right.$ to $\left.30^{\circ}\right)$ account for $55.6 \%$ of the population and $52 \%\left(24.0 \mathrm{~km}^{2}\right)$ of the total area. 
227 The glaciers were inventoried again using imagery from 1990, 2009, and 2015. These were the

228 years with suitable late-summer imagery. The quality was good to excellent with moderate

229 amounts of snow cover in some places. The summer of 2015 was a particularly low snow year

230 and the alpine landscape was largely snow-free. The root mean square error of uncertainty for

231 all outlines in each inventory was 1\% of the total area. Forty-seven more G\&PS were identified

232 in the new inventories compared to the original 1980 glacier inventory. GIS methods and

233 comparison between inventories more conclusively defined perennial features (Table 1).
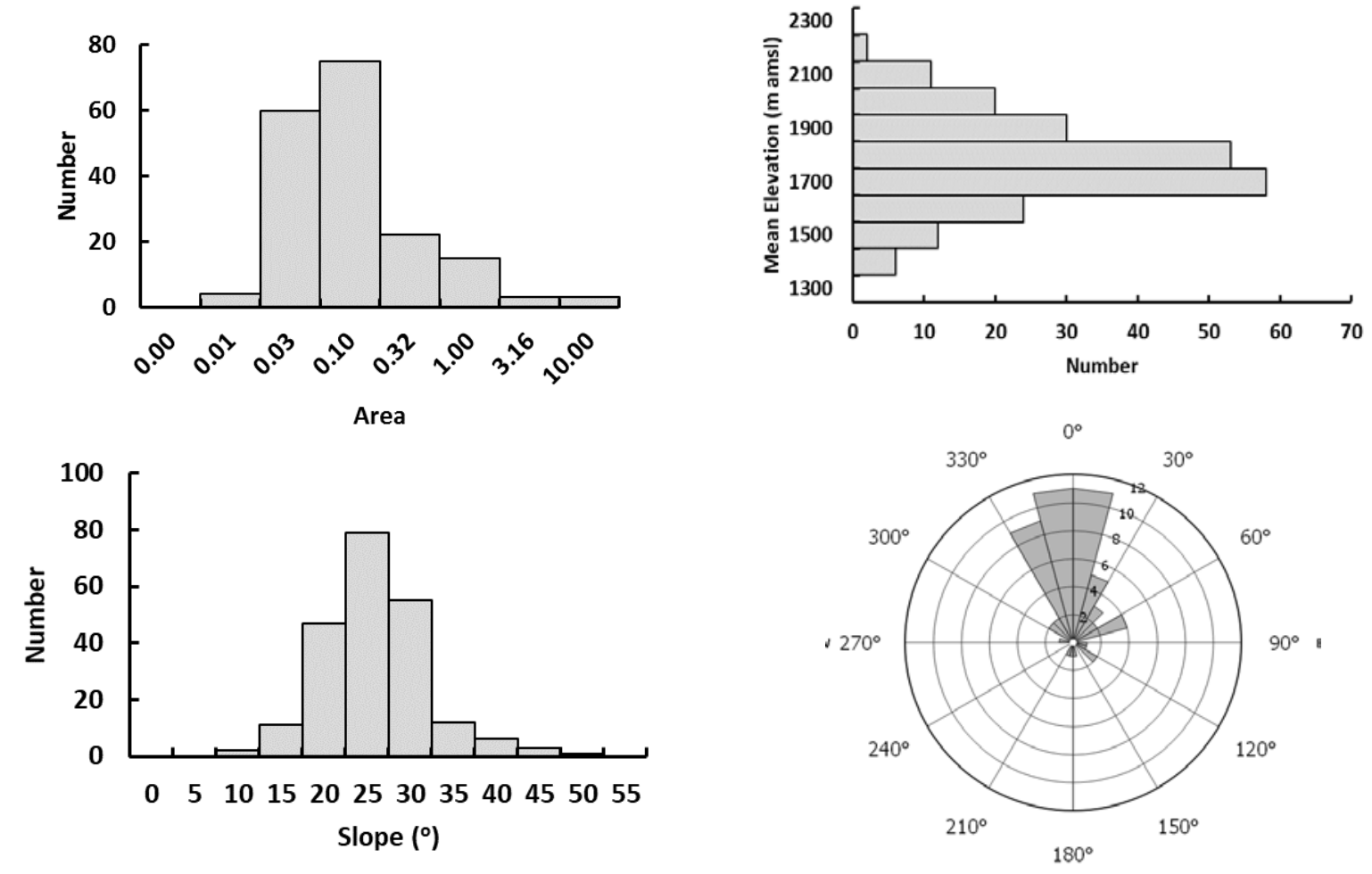

249 Figure 2. Topographic characteristics of the 1980 glacier inventory. Clockwise from upper left:

250 Frequency distributions of glacier area, mean elevation, aspect, and mean slope. For bar graphs,

251 the value of the bin is the maximum value for bin. For area, note the logarithmic values on the $x$ 252 axis. 
254 Tracking the glaciers originally identified by the 1980 inventory showed that by 2015 , total 255 glacier area decreased by $-45 \%\left(-0.59 \mathrm{~km}^{2} \mathrm{yr}^{-1}\right)$, mean glacier area decreased from $0.18 \mathrm{~km}^{2}$ to $2560.10 \mathrm{~km}^{2}$, and 35 glaciers disappeared (Table 1 Partial Inventory). The distribution of glacier 257 area in 1980 approximates a normal distribution, but becomes increasingly skewed favoring 258 smaller glaciers with time resulting in a highly skewed area-population distribution by 2015 259 (Figure 3). Given the close correspondence of fractional area change between the complete and 260 partial inventories, we estimate that about $45 \%$ of the ice-covered area was lost between 1980 261 and 2015. A total of 51 G\&PS in the complete inventory disappeared and 134 decreased below $2620.01 \mathrm{~km}^{2}$ (but $>0$ ), the minimum threshold for glacier inclusion (Fountain et al., 2017; Paul et 263 al., 2010). These very small ice masses remain in the inventory given their perennial nature and 264 their known history.

266 The time periods between inventories vary from 6 to 19 years, during which $19 \%$ - 37\% of area 267 changes were less than the uncertainty. During every time period total glacier area decreased, 268 but with one to eight glaciers increased area greater than uncertainty. No glacier increased area 269 for two or more consecutive time periods. The rate of total area change slowed from $-0.66 \mathrm{~km}^{2}$ $270 \mathrm{yr}^{-1}$ (1980-1990) to about $-0.48 \mathrm{~km}^{2} \mathrm{yr}^{-1}$ (1990-2009) before accelerating again to $-0.82 \mathrm{~km}^{2} \mathrm{yr}^{-1}$

271 (2009-2015). Of the G\&PS that disappeared, most occurred in the last period, 1990-2009.

273 Table 1. Statistics for inventories of all glaciers and perennial snowfields found in the Olympic Mountains.

274 The Complete Inventory summaries all glaciers found in each inventory and the Partial Inventory are 275 those that are common to the 1980 inventory. For area and uncertainty $\left(\mathrm{km}^{2}\right)$, Max is maximum, Min is 276 minimum, Med, is median area. Area change is the change since last inventory and can only be 277 calculated for inventories that include the same populations; $R$ Frc Chg is the relative fractional area 278 change since previous inventory and is the change (and uncertainty) divided by the area of the previous 279 inventory; T Frc Chg Is the total fractional change since the 1980 inventory; Rate Chg is the rate of area 280 change in $\mathrm{km}^{2} \mathrm{yr}^{-1}$ based on the area change and years between inventories; Total Num is the number of 281 glaciers and perennial snowfields in the inventory; Disappeared is the number that have vanished since 282 last inventory. Uncertainty is included in smaller font, and is the root mean square error except for the 
283 mean, which is the standard deviation. The 2009 inventory was originally published in Riedel et al ( 284 2015).

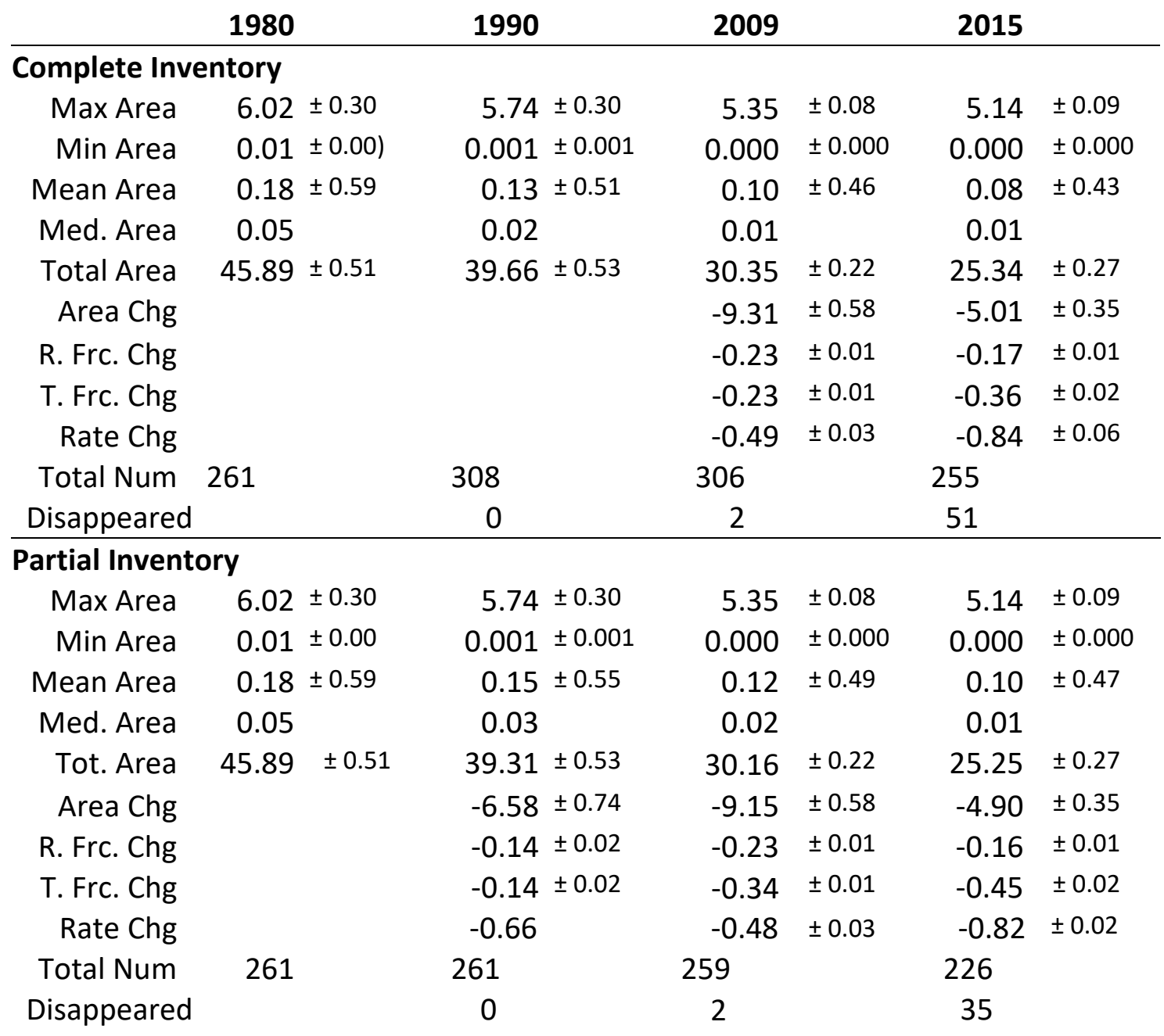



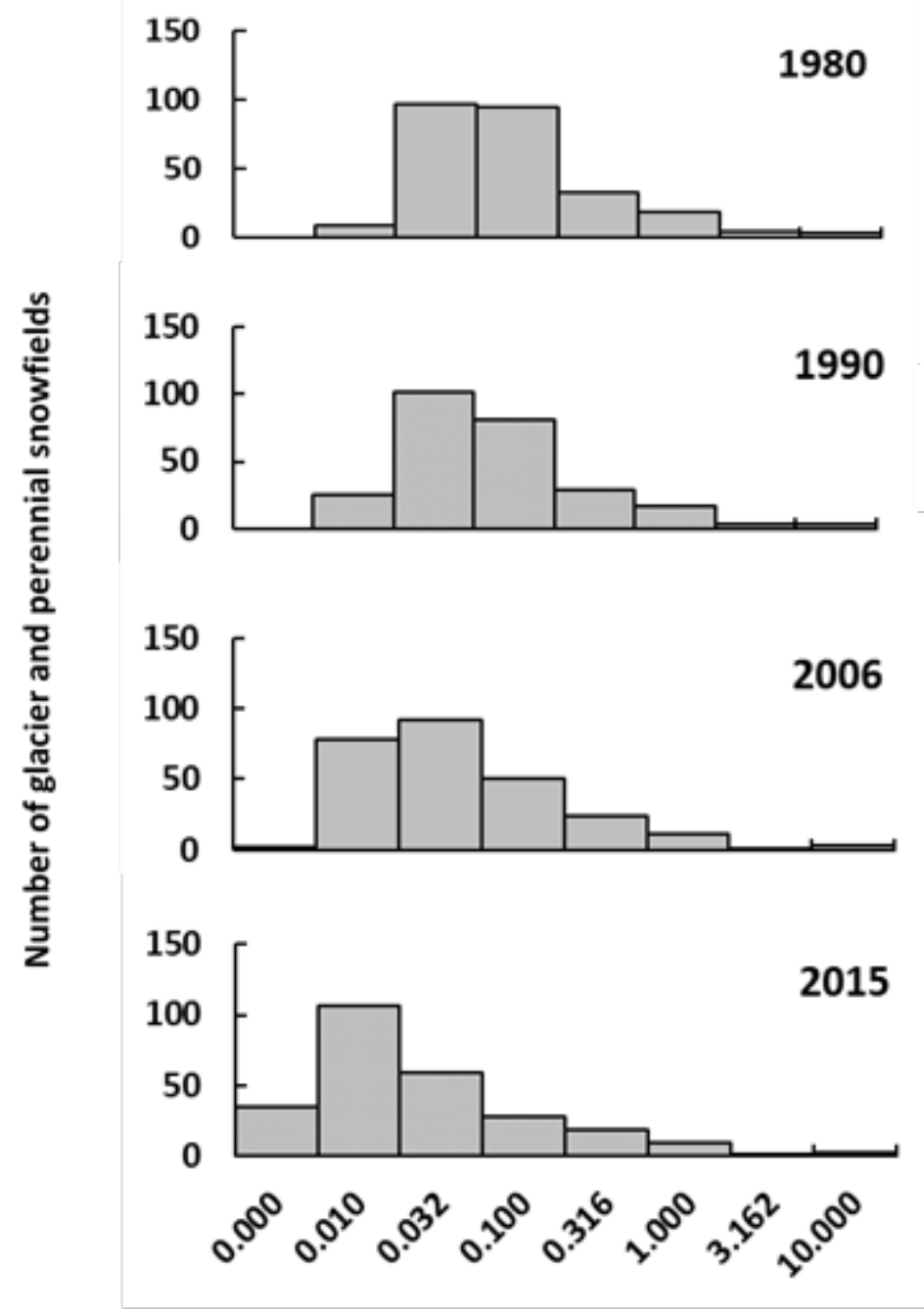

Area $\left(\mathrm{km}^{2}\right)$

286 Figure 3. The number of glaciers as a function of their area for each of the inventories. The

287 horizontal axis intervals are logarithmic increasing by a power of 0.5 ; tick labels on the $x$-axis

288 represents maximum bin value. The G\&PS in the zero column are those that disappeared since

289 the previous inventory.

290

291 4. Analysis

292

$293 \quad 4.1$ Effect of Topography 
To examine the influence of topographic factors, such as elevation and aspect, on glacier area change, the change was first normalized by dividing by initial area yielding a fractional area change. Results show that smaller glaciers shrink proportionally more than larger glaciers but the variability of shrinkage is also much larger. Much of the variability in very small glaciers is probably due to local topographic effects, such as topographic shadowing by valley walls or local snow accumulation via avalanching and wind drift (Basagic \& Fountain, 2011; DeBEER \& Sharp, 2009; Kuhn, 1995). In contrast, local boundary conditions affect larger glaciers much less. In order to minimize boundary effects, the glaciers $<0.1 \mathrm{~km}^{2}$ were eliminated from the topographic analysis.

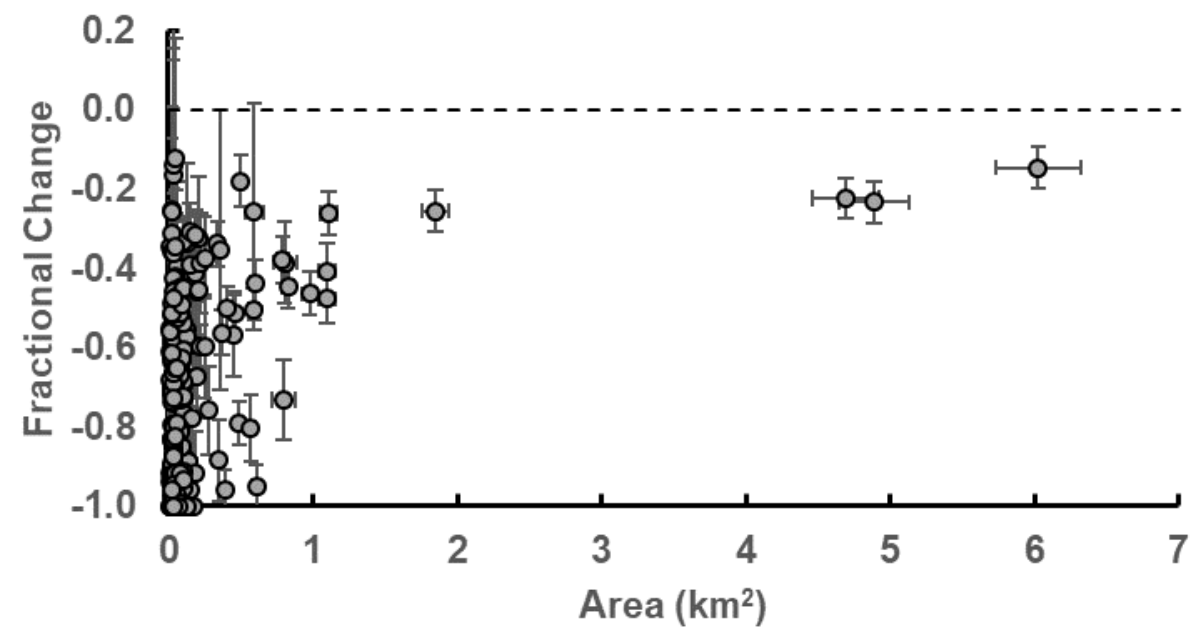

304 Figure 4. Fractional area change of the glaciers and perennial snowfields in the Olympic

305 Mountains as a function of initial area from 1980 to 2015 using the only the glaciers identified in 3061980.

308 No correlation of fractional area change was found with area, aspect, slope, distance from the 309 Pacific Ocean, winter precipitation or average seasonal temperature (summer, winter). The only 310 correlative factor was elevation (Figure 5). Area changes were further examined by sorting the 311 entire data set, including the small G\&PS, from greatest to least, then subdivided into four 312 groups. The topographic and climatic characteristics of the group with the largest change ( $\geq$ - 
$31392 \%)$ were compared to those of the smallest change ( $\leq-51 \%)$. Each group consisted of about

31455 glaciers. For glaciers with the largest relative change, almost half (21) disappeared, had a

315 lower maximum elevation ( $\Delta-250 \mathrm{~m}$ ). Although no significant differences were observed for the

316 other variables, the glaciers with the largest fractional change tended to be smaller (mean of

$3170.06 \mathrm{~km}^{2}$ versus $\left.0.56 \mathrm{~km}^{2}\right)$, and warmer $\left(\Delta+0.7^{\circ} \mathrm{C}\right)$ air temperature in summer and winter,

318 consistent with a lower elevation (Table A1).

320 To examine the effect of the distribution of glacier area with elevation the hypsometry index

321 was compared with fractional area change. The index is a ratio of the elevation differences

322 between the maximum and median and the median and minimum (Jiskoot et al., 2009). For

323 example, if the elevation difference above the median is smaller than below the median it

324 implies a shallow broad accumulation zone compared to a longer, narrower ablation zone. We

325 expected that glaciers with a greater elevation extent above the median than below exhibit less

326 area change over time. No pattern was found; accounting for aspect, elevation, or local climate

327 provided no improvement.

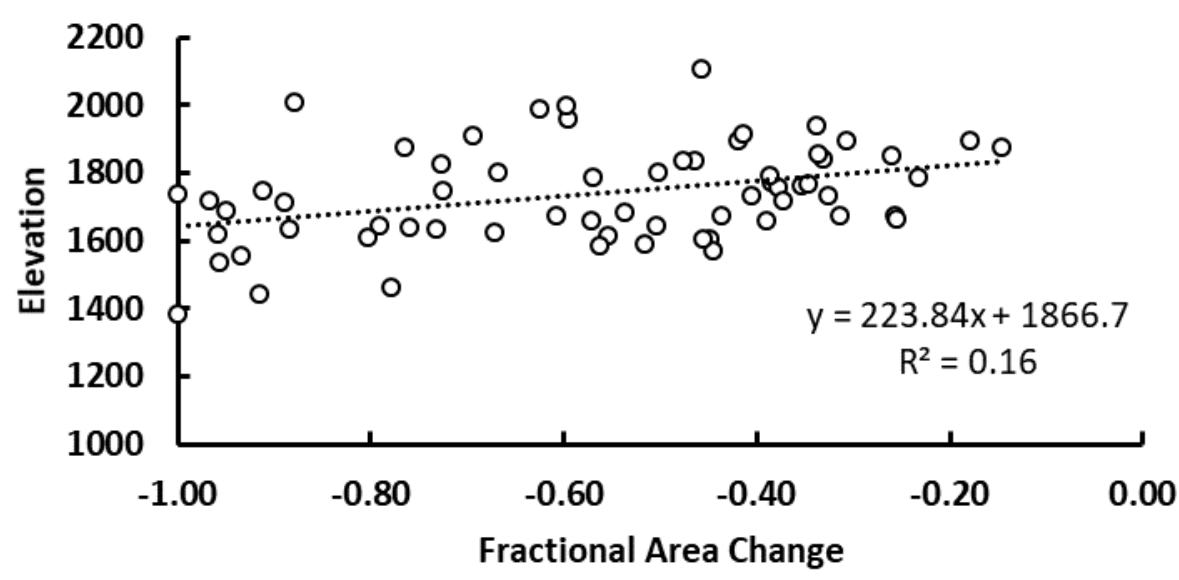

332 Figure 5. The factional area change (1980 to 2015) of glaciers and perennial

333 snowfields $\left(>0.1 \mathrm{~km}^{2}\right)$ with elevation. 
337 The SnowEx lidar surveyed 216 of 261 glaciers (83\%) identified by 1980 inventory. In terms of 338 that inventory those 216 glaciers account for $43.0 \mathrm{~km}^{2}(94 \%)$ of the total $45.9 \mathrm{~km}^{2}$ area. The 339 estimated volume change between 1980 and 2015 is $-0.694 \pm 0.164 \mathrm{~km}^{3}$ with a specific average 340 volume change of $-16.1 \pm 3.8 \mathrm{~m}$. If this average is applied to the 45 glaciers not included in the 341 lidar survey, the total estimated volume change is $-0.741 \pm 0.164 \mathrm{~km}^{3}$. No significant spatial 342 trends were observed with mean glacier elevation, slope, latitude, or longitude. If we assume 343 that all mass loss from storage occurs during the months of August and September, the period

344 in which seasonal snow is at a minimum and maximum ice is exposed, then the contribution to 345 stream runoff is about $347,000 \pm 77,000 \mathrm{~m}^{-3} \mathrm{dy}^{-1}$.

347 We estimated the remaining ice volume in 2015 using an area - volume scaling relation (Bahr et 348 al., 2015). For glacier area, S, the volume, V, can be estimated as,

$$
\mathrm{V}=\mathrm{cS}^{\gamma}
$$

352 with $c$ and $\gamma$ as undefined parameters. We used parameter values from the literature including 353 those based on theoretical grounds (Bahr et al., 2015) and on empirical results (Chen \& 354 Ohmura, 1990; Farinotti et al., 2009). Five estimates of volume were generated. The high and 355 low volume estimates were eliminated and the middle three were averaged, those included 356 Chen and Ohmura's (1990) categories of 'for the Cascades and other areas', 'for Cascades, small 357 glaciers'; and Farinotti et al., (2009), yielding, $0.75 \pm 0.19 \mathrm{~km}^{3}$. The uncertainty is the standard 358 deviation of the estimates. The Cascades refers to the mountain range $100 \mathrm{~km}$ northeast of 359 the Olympics and it has a similar climate regime. From this estimate volume and the volume 360 change, the estimated total volume of all glaciers in 1980 is $1.49 \pm 0.25 \mathrm{~km}^{3}$. 
364 To investigate glacier change more closely we focus on the glaciers mantling Mt. Olympus, the 365 highest peak (2,432 $\mathrm{m})$ in the Olympic Mountains, representing 61\% of the total glacier area in 366 the region including the four largest glaciers and 6 of the 19 named glaciers. From 1980 to 3672015 , the glaciers lost about $0.42 \mathrm{~km}^{3}$ (61\% of total, Figure 6). The specific volume change for 368 all glaciers was $-20 \pm 4 \mathrm{~m}$, ranging from $-30 \pm 5 \mathrm{~m}$ (Humes Glacier) to $-6 \pm 4 \mathrm{~m}$ for one of the 369 smaller unnamed glaciers. For Blue Glacier, the largest glacier, the specific volume change was $37022 \pm 4 \mathrm{~m}$.

371

372 The distribution of glacier area shifted to higher elevations, although the elevation of maximum 373 area, 1700-1750 m, had not changed. (Figure 6). The fractional area change with elevation 374 generally followed the fractional volume change with maximum change (decrease) at about $3751500 \mathrm{~m}$. For elevations above about $1950 \mathrm{~m}$, glacier area remained constant but thinned. 376 Specific volume, above $1250 \mathrm{~m}$ shows a rapid decrease with elevation until about $1900 \mathrm{~m}$ 377 where it reaches a relatively constant value of about $-9 \mathrm{~m}$. Below $1250 \mathrm{~m}$ glacier area is much 378 smaller and some of it is debris-covered.

379 

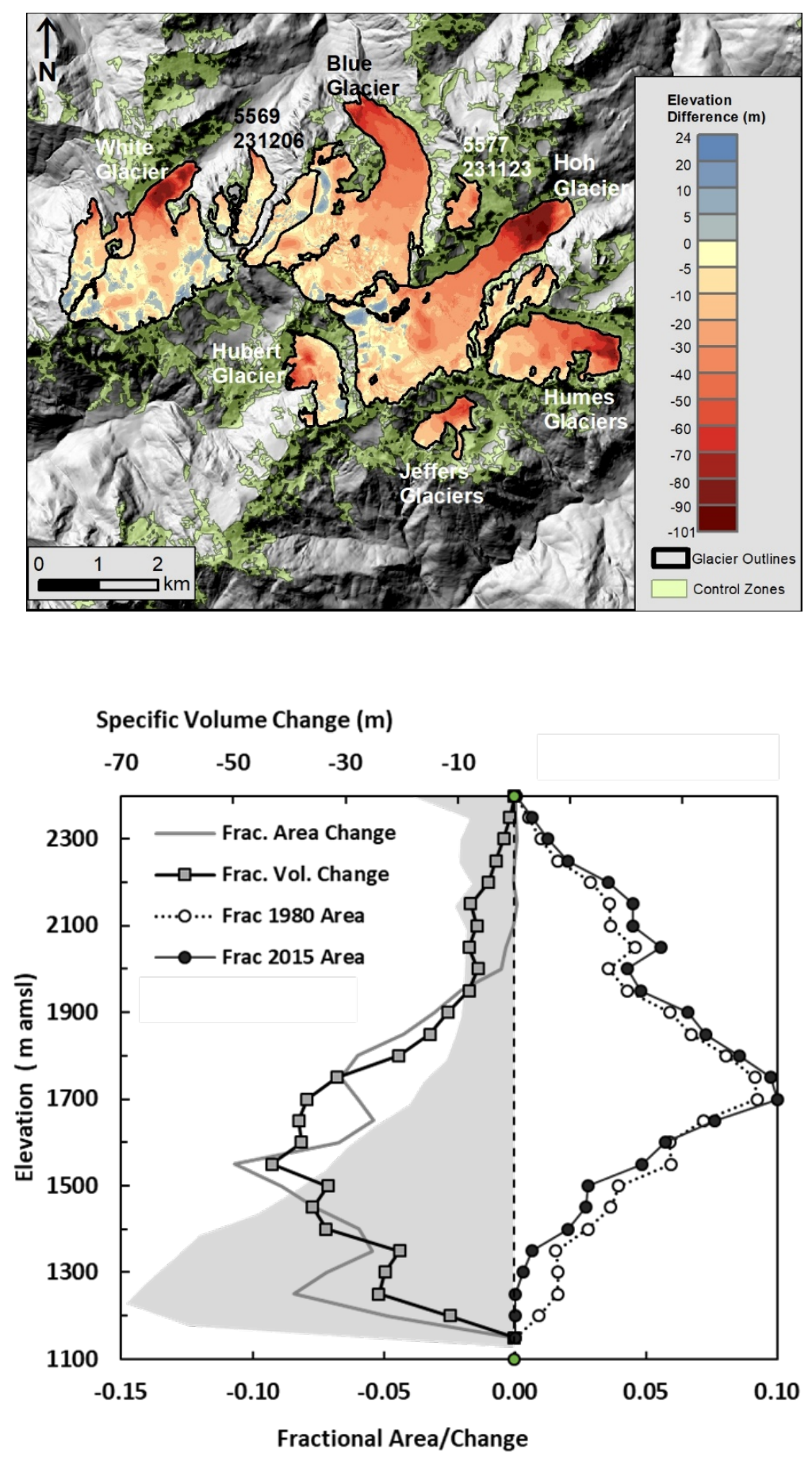
Figure 6. Area and volume changes of the glaciers $n$ Mount Olympus (1980-2015) as a function

384 of elevation, in $50 \mathrm{~m}$ intervals. The top image shows the elevation change of all the glaciers. The 385 numbers identify the unnamed glaciers, the 55XX is the record number of Fountain et al. (2017) 386 and the 231XXX number is the hydrolD of Spicer (1986). The bottom graph is the glacier change 387 averaged over 50 m elevation bands. Frac is the fraction of total and Vol is volume. Specific 388 volume change, shaded, is the volume change per unit area with an uncertainty of $\pm 4 m$.

To test whether the changing glacier area on Mt. Olympus is representative of the other

391 glaciers in the region the two were compared using the compiled inventories (Figure 7). Results 392 show the two are highly correlated. The linear correlation suggests that should all the other 393 glaciers disappear the area of those on Mt. Olympus shrinks to about $12.5 \mathrm{~km}^{2}$.

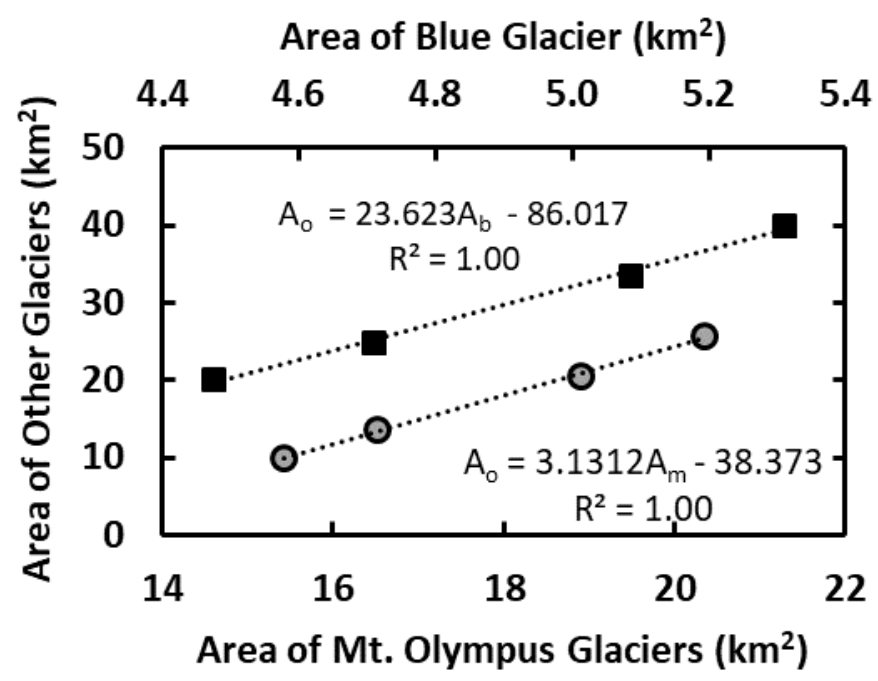

395

396 Figure 7. Area of all the glaciers in the region, except those on Mt. Olympus, plotted with 397 respect to the area of the glaciers on Mt. Olympus (grey dots), and the area of all glaciers 398 including those on Mt. Olympus, except Blue Glacier, plotted against the area of Blue Glacier 399 alone (black squares). Linear regressions are shown. $A_{o}$ is the area sum of all the other glaciers 400 in the Olympic Mountains, not including those of the independent variable. $A_{m}$ is the area of all 401 glaciers on Mt. Olympus and $A_{b}$, the area of Blue Glacier. 
403 The most extensively studied glacier in the Olympic Mountains is Blue Glacier, dating back to 404 the late 1950s (Conway et al., 1999; LaChapelle, 1959; Rasmussen et al., 2000; Spicer, 1989).

405 Because of this activity and interest, the glacier area has been well-documented over time 406 (Figure 8). The pattern shows equilibrium for the first two decades of the $20^{\text {th }}$ Century, followed 407 by rapid retreat that ended in the middle 1940s. The glacier was stable/advancing slightly over 408 the next 40 years, peaking in the early 1980's. Note the stability in the late 1970's to early 4091980 's, the period of time when the Spicer and the USGS were making glacier maps of the 410 region. By the 1990's the glaciers were in rapid retreat continuing through to 2015. Based on 411 the correlation shown in Figure 7, the changes in the glacier area for the Olympic Mountains 412 should vary in a similar manner. The estimated total area in 1900 is $55.3 \mathrm{~km}^{2}$, more than twice 413 the 2015 area of $25.3 \mathrm{~km}^{2}$.

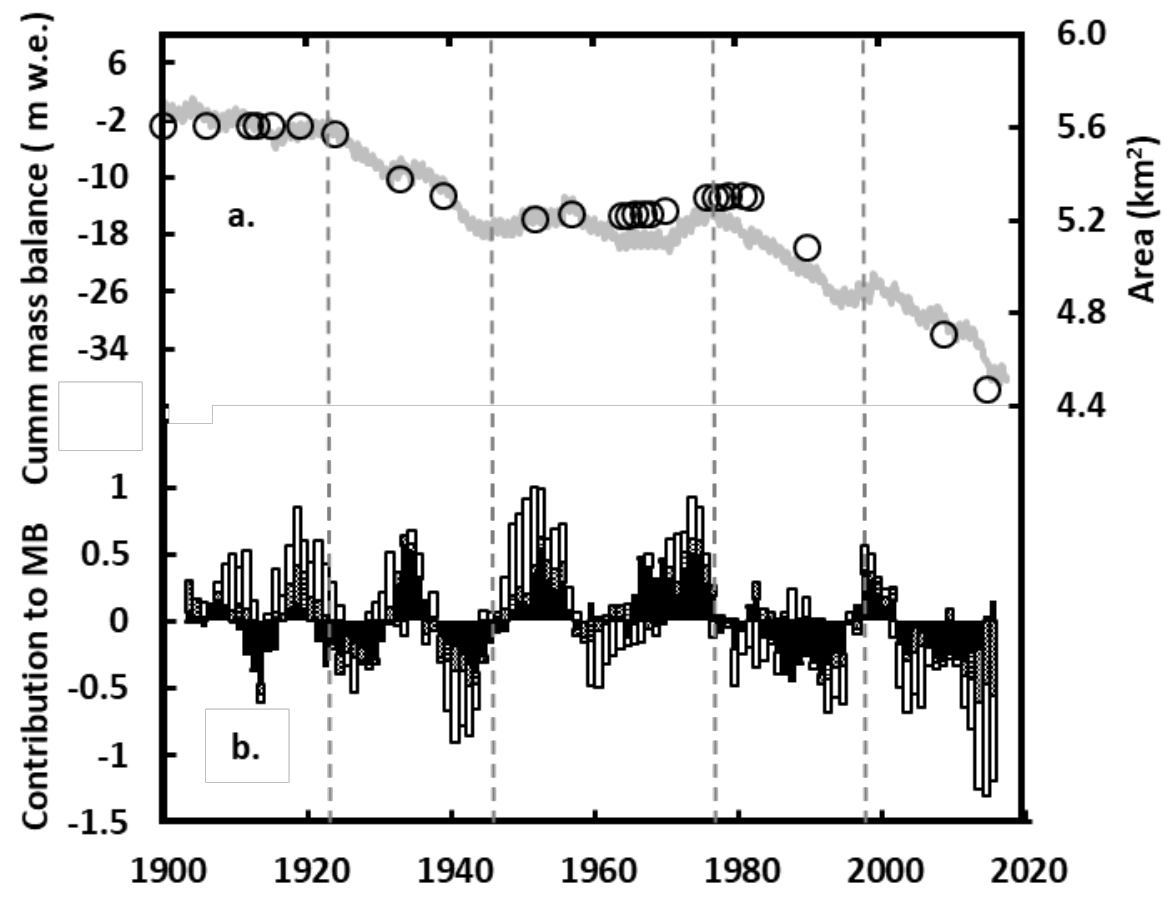

415 Figure 8. Changes of Blue Glacier and mass balance drivers. a. Area change of Blue Glacier since 4161900 (circles) and estimated cumulative (cumm) monthly mass balance (grey line). Area data 417 prior to 1990 from Spicer (1989), see Table A2. The vertical dashed lines are climate regime 
418 shifts of the North Pacific 1923, 1946, 1977, and 1998 (see text). b. Contribution to the mass 419 balance (MB) departures (5-year running mean) from winter accumulation (black), winter air

420 temperature (white), and summer air temperature (cross hatched) departures

421

$422 \quad 4.4$ Climate Change and Glacier Mass Balance

423

424 The climate of the Olympic Mountains is maritime, with relatively warm winters with abundant

425 precipitation followed by cool dry summers (Figure 9a). The accumulation and ablation seasons

426 were defined using air temperature. Winter was defined for those months when the minimum

427 and mean (average of the maximum and minimum) temperatures $<0^{\circ} \mathrm{C}$; and included

428 December through March. Monthly maximum temperatures were commonly $>0^{\circ} \mathrm{C}$. Summer 429 was defined for those months in which the minimum temperatures were $\geq 0^{\circ} \mathrm{C}$; and included 430 May through October. The transition months are November and April. The net balance year 431 nominally starts in November and ends in October.

433 To determine how temperature and precipitation has changed over the past century, the 434 monthly averages of the first 50 years of record were subtracted from the monthly averages of 435 the last 20 years (Figure 9b). For all months, the average air temperature warmed by $+0.5^{\circ} \mathrm{C}$ and 436 precipitation increased by $+171 \mathrm{~mm}(+8 \%)$. Summer air temperatures warmed by $+0.4^{\circ} \mathrm{C}$ and 437 precipitation slightly decreased $-8 \mathrm{~mm}(-1 \%)$; for winter, temperatures warmed by $+0.7^{\circ} \mathrm{C}$ and 438 precipitation increased by $+47 \mathrm{~mm}(+2 \%)$. For specific months, monthly air temperatures 439 warmed the most in midwinter (January, $+1.8^{\circ} \mathrm{C}$ ) and in mid-summer (August, $+0.9^{\circ} \mathrm{C}$ ).

440 Precipitation changed little except for greater precipitation in October and November, months 441 when the average air temperature is above freezing. 
a.

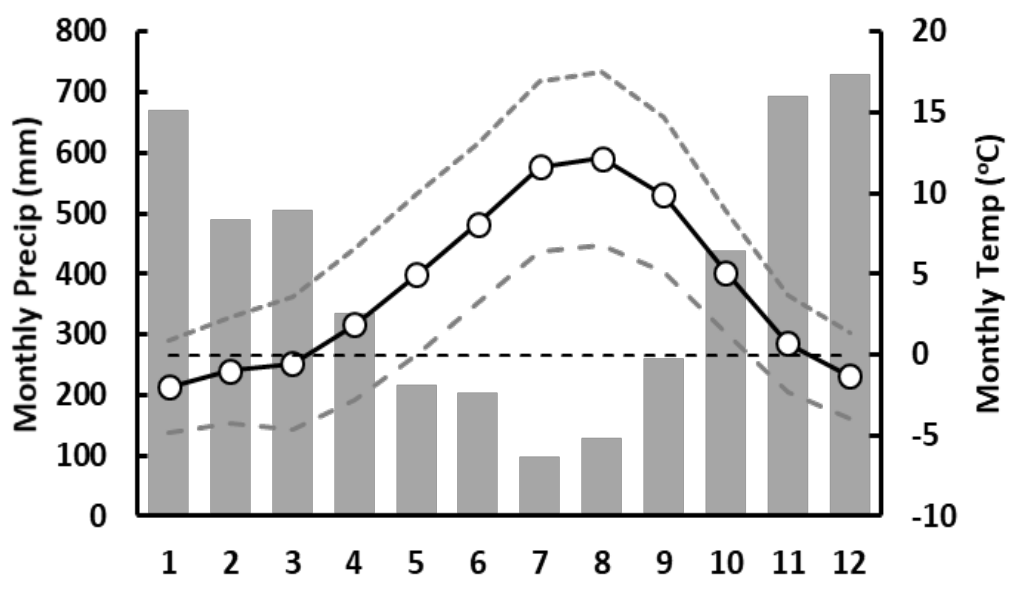

b.

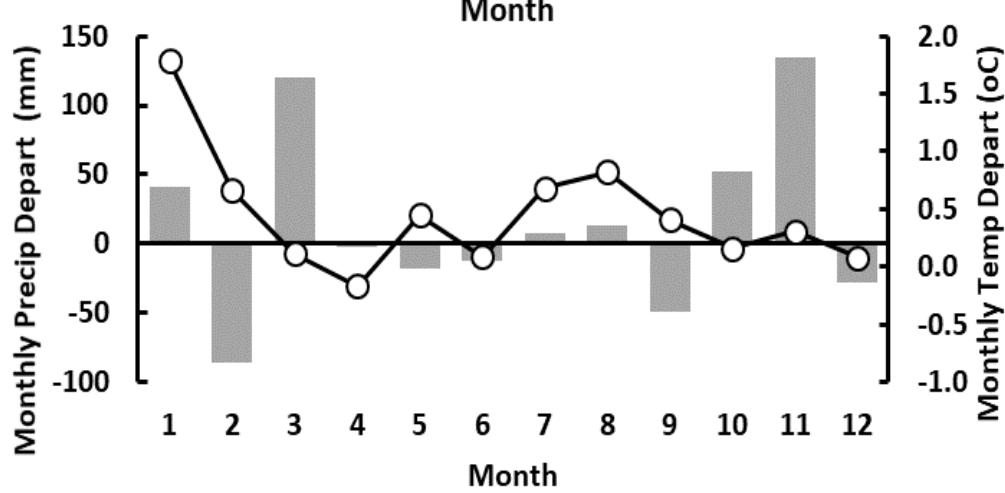

443 Figure 9. Climate of the Mt. Olympus region from averaged monthly PRISM data (Daly et al.,

444 2007), (a) over period 1900 - 2017. The bars represent precipitation (precip); the gray dashed

445 and black solid curves are minimum, mean, and maximum air temperature (temp). The mean is

446 an average of the maximum and minimum values. The fine horizontal dashed line represents

$4470^{\circ} \mathrm{C}$. The second panel (b) are the departures in mean temperature and monthly precipitation

448 between the average of the first 50 years of record and the last 20 years.

450 The time series of air temperature and precipitation show a century-scale warming trend for

451 both summer and winter temperatures but no trend in precipitation (Figure 10). At decadal

452 scales both temperature and precipitation vary. Warming winter temperature is particularly

453 important because it is already near $0^{\circ} \mathrm{C}$ and further warming changes the phase of

454 precipitation from snow to rain, reducing snowfall (mass gain) to the glaciers. 


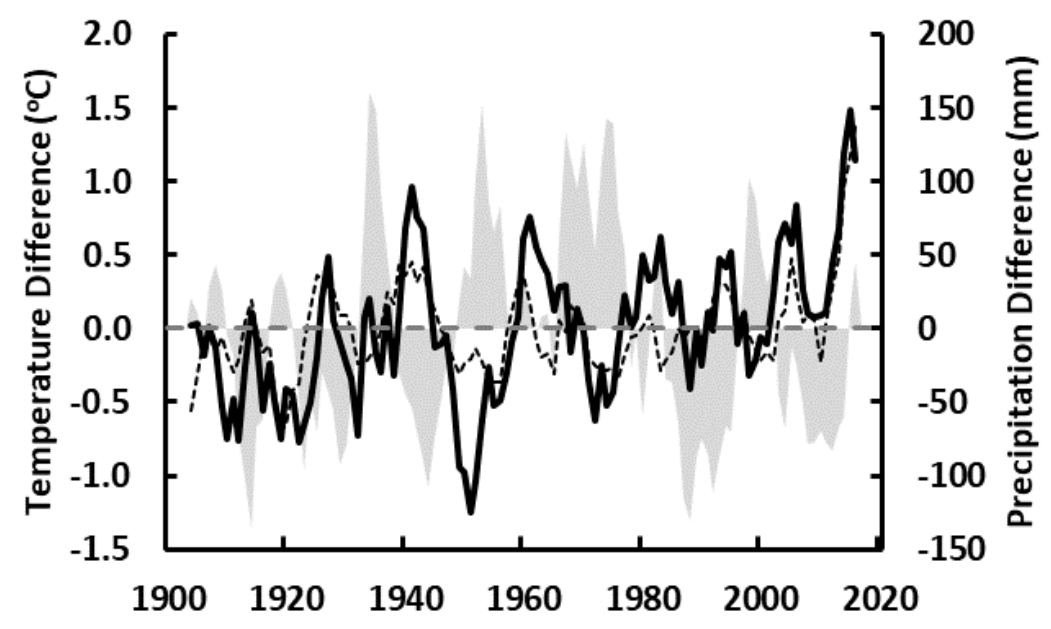

455

456 Figure 10. Difference from the mean (1900-2017) seasonal air temperature and precipitation,

457 with a 5-year running mean applied, Mt Olympus, WA. The light solid grey is winter

458 precipitation, the solid black line is winter temperature the dotted line is summer temperature.

460 To examine how glaciers in the Olympic Mountains respond to climatic variations we use Blue

461 Glacier as a proxy because its area has been well-documented over the past century, its change

462 correlates well with regional area changes, and mass balance has been measured at the glacier

463 (Armstrong, 1989; Conway et al., 1999; LaChapelle, 1965). We use a simple model of glacier

464 mass balance to provide a more direct link to climate, rather than observed changes in area

465 that also responds to dynamic readjustment (Cuffey \& Paterson, 2010). The model is simple and

466 based on monthly PRISM values of precipitation and air temperature over the entire glacier

467 (Daly et al., 2007; McCabe \& Dettinger, 2002; McCabe \& Fountain, 2013). Three adjustable

468 parameters are required, two of which define the phase of precipitation for snow

469 accumulation, the threshold temperatures for snowfall $\left(\leq-2^{\circ} \mathrm{C}\right)$, and for rain $\left(\geq+2^{\circ} \mathrm{C}\right)$. For

470 temperatures between the snow/rain thresholds the ratio linearly changes from 1 to 0.

471 Coincidently, Rasmussen et al (2000) found empirically that snowfall occurred in the

472 accumulation zone of the glacier at air temperatures $\leq-2^{\circ} \mathrm{C}$. One adjustable parameter is

473 required to estimate ablation and defines the rate of melt as a function of air temperature. The

474 monthly mass balance is then the sum of snow accumulation and ablation. We recognize the 
475 limitations of this simple model, but use it here to understand the variations in mass balance, 476 caused by changes in air temperature and precipitation, rather than for predictive values of 477 mass balance.

479 Variations in the estimated mass balance closely matches the variations in glacier area over 480 time (Figure 8). The cumulative mass balance over the period 1987-2015 is -17 m w.e. and 481 compares favorably with the specific volume change -20 m w.e. \pm 4 m (-22 m \pm 4 m elevation 482 change) over the same period. Comparison with the estimated cumulative mass balance of Blue 483 Glacier (1956-1997) by Conway et al. (1999), is good, although their mass balance increase in 484 the 1980s was not apparent in our model. Comparisons to measured mass balances of five 485 glaciers in the Cascade Range were also favorable in terms of synchronous change and 486 magnitude (Riedel \& Larrabee, 2016). Of the five glaciers the cumulative mass balance most 487 closely resembled Sandalee Glacier.

489 Annual mass balance is best correlated with accumulation $\left(R^{2}=0.98\right)$ and less so with the 490 ablation (-0.79). Accumulation is correlated equally with winter air temperature $(-0.61)$ and 491 winter precipitation (+0.61). Ablation, as expected, is highly and inversely correlated with 492 annual, winter, and summer temperatures $(-0.98,-0.74,-0.84$, respectively). Taken together, 493 this is suggestive of the important role of air temperature in determining mass balance with 494 precipitation playing a secondary role. To investigate the role of air temperature further, all 495 variables were rescaled as mean standardized departures and a multiple linear regression was 496 calculated to predict the model mass balance from annual air temperature and winter 497 precipitation. The regression yielded a correlation coefficient of $\left(R^{2}=0.85\right)$ and the correlation 498 between the two independent variables was insignificant $\left(R^{2}=0.001, p=0.69\right)$. The relative 499 importance of each independent variable on the mass balance was evaluated by multiplying the 500 time series of each independent variable by its regression coefficient (McCabe \& Wolock, 501 2009). Annual air temperature accounted for $83 \%$ of the variability in the root mean square 502 value of mass balance whereas winter precipitation accounted for $53 \%$. The regression was run 503 again but with three independent variables, winter precipitation, summer air temperature and 
504 winter air temperature, to define which seasonal air temperature was most influential. The 505 regression yielded a slightly lower correlation $\left(R^{2}=0.82\right)$; and winter precipitation, summer, 506 winter air temperatures accounted for $56 \%, 28 \%$, and $68 \%$ of mass balance variability,

507 respectively. Of the seasonal air temperatures, winter is more important. The time series of the

508 contribution to the total mass balance departure was smoothed with a 5-year running mean

509 and show that winter precipitation and winter air temperature vary most (Figure 8b). The mid-

510 century cool period 1946-1977 shows two episodes of cool winter air temperatures (positive

511 departures of mass balance) simultaneously with two episodes of positive precipitation

512 departures. The two episodes are separated by a warm winter period (negative mass balance

513 departures) and average winter precipitation.

515 To examine the influence of broader climate patterns, monthly values of mass balance, air 516 temperature, and precipitation were smoothed with a 12-month central running mean and 517 correlated with the climate indices (Table A3). The highest correlations were found between 518 the PDO, PNA, and NP with monthly air temperatures $\left(R^{2}=+0.53,+0.64,-0.58\right.$ respectively $)$ and 519 with mass balance $(-0.52,-0.59,-0.56$ respectively). Note that PDO, PNA, and NP are highly 520 inter-correlated (e.g. PDO-PNA,+0.66; PNA-NP, -0.71) as are air temperature and mass balance 521 (-0.74). Lesser correlations were found with Nino 3.4 and SOI for temperature $(+0.52,-0.47)$, 522 and for mass balance $(-0.43,+0.40)$. Correlations between precipitation and the indices did not 523 exceed \pm 0.19 and the correlation between air temperature and precipitation was also low, -

524 0.12. Therefore, at annual time scales, PDO, PNA, and NP are the most influential atmospheric 525 patterns on air temperature and mass balance.

527 The shifts in the mass balance of Blue Glacier coincide with regime shifts of sea surface 528 temperatures in the North Pacific Ocean, which are typically related to the Pacific Decadal 529 Oscillation PDO. Shifts occur in 1923, 1946, 1977, and 1998 (Figure 8) (Bond, 2003; Gedalof \& 530 Smith, 2001; Jo et al., 2015; Litzow \& Mueter, 2014; Mantua \& Hare, 2002; Minobe, 2002;

531 Overland et al., 2008), and 1998 (Hare \& Mantua, 2000; Jo et al., 2015; Minobe, 2002). No clear 532 response is observed with the 1989 shift suggested by (Hare \& Mantua, 2000). The periods of 
533 glacier stability, 1890-1924, and 1947-1976 are associated with "cool" PDO regimes, whereas

534 periods of glacier recession, 1925-1946, and 1977-1998, are associated with "warm" PDO

535 regimes (Mantua and Hare, 2002). These data show that the mass balance of Blue Glacier

536 specifically, and by implication those in the Olympic Mountains, are very sensitive to the sea

537 temperatures conditions of the North Pacific.

\section{The Glacier Future to 2100}

541 To predict the future extent of the glaciers in the Olympic Mountains we applied the Regional

542 Glaciation Model (RGM) developed by Clarke et al (2015) in modified form. The RGM is a

543 distributed 2-dimensional, plan-view model. It grows glaciers from a bare-earth landscape at

544 time steps of one year. The bare-earth landscape at $25 \mathrm{~m}$-scale digital elevation model is

545 estimated by removing the glaciers identified by the Randolph Glacier Inventory using a surface

546 inversion (Huss \& Farinotti, 2012; Pfeffer et al., 2014). The final bare-earth landscape was

547 rescaled to $100 \mathrm{~m}$. To drive the RGM model, monthly meteorological fields from a global climate 548 model (GCM are downscaled. The Community Climate System Model 4 (CCSM4, Gent et al., 549 2011) generated these fields under various emission scenarios for the future. These scenarios 550 are described as Regional Concentration Pathways (RCP, Van Vuuren et al., 2011) for different 551 climate scenarios of low $\left(2.6 \mathrm{~W} \mathrm{~m}^{-2}\right.$ of additional forcing by 2100$)$, moderate $\left(4.5 \mathrm{~W} \mathrm{~m}^{-2}\right)$, or

552 "business as usual" (8.5 $\left.\mathrm{W} \mathrm{m}^{-2}\right)$, respectively. The GCM simulations of air temperature, 553 precipitation, and solar radiation are provided for grid cells $1^{\circ} \times 1^{\circ}$ (latitude, longitude) and one 554 cell covered the model domain. Spatial variation in air temperature and precipitation across the 555 model domain was estimated using the Parameter-elevation Relationships on Independent 556 Slopes Model (PRISM, Daly et al., 2007), an 800 m gridded data set based on weather station 557 measurements and rescaled to $100 \mathrm{~m}$ to match the digital elevation model. Monthly PRISM 558 values, averaged over the period 1980-2010, subtracted from the GCM value, also averaged 559 over the same period, producing a cell by cell offset for temperature and precipitation (Gray, 560 2019). We assume the spatial offsets do not change with time. The spatial pattern of solar 561 radiation is calculated from the solar position at a constant solar angle for that month and the 
562 value from the GCM is distributed accordingly. Finally, snow accumulates on the landscape

563 when precipitation occurs at air temperatures below $0^{\circ} \mathrm{C}$. Snow and ice melt are estimated

564 from a degree-day melt model and exposure to solar radiation.

566 Initial results showed that model could not predict the presence of glaciers in part of the 567 domain, east of Mount Olympus, despite extreme adjustments to the parameters. We

568 concluded that the source of the problem was snow accumulation through direct snowfall and 569 secondary sources of avalanching and wind redistribution. Significant uncertainty plagues 570 spatially distributed precipitation in mountainous regions (Gutmann et al., 2012; Livneh et al., 571 2014). And secondary sources make important contributions to small glaciers (Frans et al., 572 2018; Kuhn, 1995). Precipitation was increased by a factor of 3 over the footprint of the glaciers 573 producing reasonable results for glacier location and extent, similar to the approach of (Clarke 574 et al., 2015). Results showed the total area of modeled ice in 1980 was $106 \%$ of measured and 575 in $2015,97 \%$. About $60 \%$ of the glaciers were correctly placed. This mismatch is not of great 576 concern given the coarseness of the model, in terms of spatial resolution and approximation of 577 the mass balance processes.

579 Over time the model shows a dramatic loss of ice (Figure 11). For the RCP 8.5 "business as 580 usual" scenario shows that the glaciers will largely vanish by about 2070. With a moderate 581 reduction in greenhouse gases (RCP 4.5) the total glacier area will be reduced to a few $\mathrm{km}^{2}$ at 582 most and limited to Mt. Olympus. The spikey character of the glacier area plot is typical of 583 widely dispersed small glaciers (Clarke et al., 2015). 

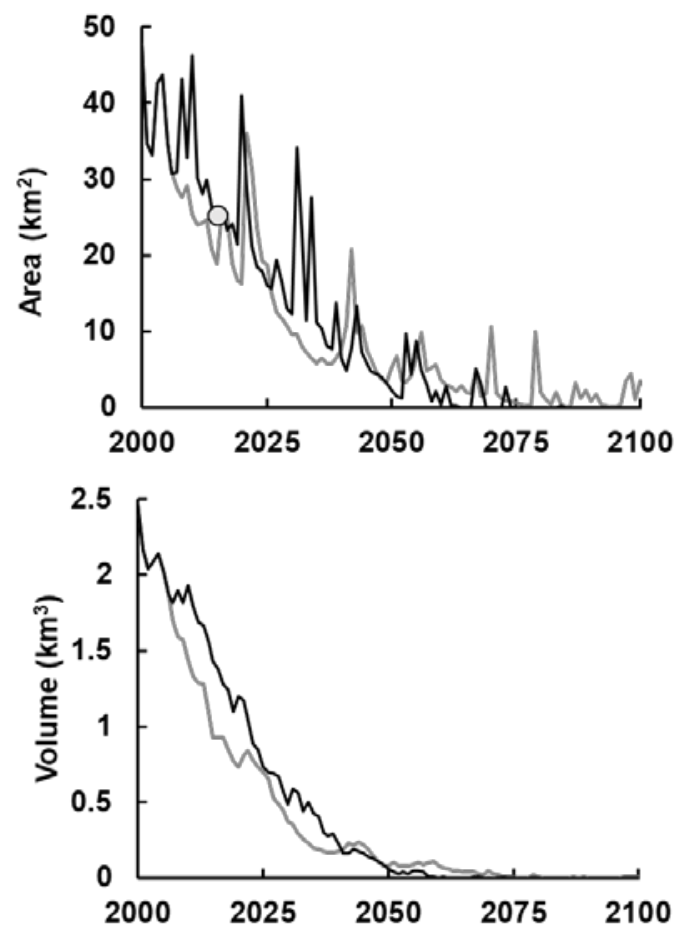

590 Figure 11. Predicted area and volume for the glaciers of the Olympic Peninsula. The black line is 591 RCP 8.5 'business as usual' scenario, and the grey line is the RCP 4.5 modest reduction (Van

592 Vuuren et al., 2011). The dot in the area plot is the measured glacier area in 2015.

594 6. DISCUSSION

596 Our method of inventorying differed from the original inventory (Spicer, 1989) due to new 597 technology and digital imagery. This posed some challenges to developing a seamless series of 598 inventories over time. The methodological difference highlighted an important and often 599 overlooked issue. When updating an inventory completed by different authors, original 600 methods must be understood in order to minimize apparent changes in area resulting from 601 methodological differences (Paul et al., 2010; DeVisser and Fountain, 2015; Riedel and 602 Larrabee, 2016). This is also true for individual glaciers where interpretations of a glacier 603 boundary may differ dramatically between investigators. It is not so much a matter of boundary 604 interpretation as assumptions regarding which tributary or connected ice-covered landscape to 605 include. Imagery resolution is also important. Our new inventories were compiled from aerial 
606 photographs or high-resolution satellite imagery both with a spatial resolution $\leq 1 \mathrm{~m}$. This 607 resolution seemed suitable for outlining small glaciers $\left(\geq 0.01 \mathrm{~km}^{2}\right)$ and certainly provides a 608 much better accuracy than $15 \mathrm{~m}$ resolution Landsat (Fischer et al., 2014). Also, compiling 609 inventories for more than one set of imagery is advantageous because although a single author 610 may compile the two new inventories some adjustment between inventories is required 611 because shifting assumptions during the data collection period. A second author complied the 612 last inventory and had to reconcile those outlines against the prior two inventories. This 613 minimized interpretation error over time.

614 The inventories are split into two categories. The partial inventories track only those 261 615 glaciers $\geq 0.1 \mathrm{~km}^{2}$, identified in 1980 by Spicer (1986). The complete inventories, starting in 616 1990, include initially 308 glaciers and perennial snowfields $\geq 0.01 \mathrm{~km}^{2}$. Although the

617 inventories differ by 47 features, the total areas did not differ by more than $0.35 \mathrm{~km}^{2}$ and the 618 trend with time did not differ. To maintain the longest record the results from the partial 619 inventories are summarized.

621 The Olympic Mountains are populated by small glaciers, as of 2015 the average area was 0.08 $622 \mathrm{~km}^{2}$, and they have been shrinking over time like other regions in North America and elsewhere 623 globally (Abermann et al., 2009; DeBEER \& Sharp, 2007; DeVisser \& Fountain, 2015). Thirty-five 624 glaciers and 16 perennial snowfields have disappeared. The pattern of change is also similar 625 with the smaller glaciers exhibiting a wide range of shrinkage, but generally shrinking faster, 626 than the larger glaciers, which exhibit a smaller range of shrinkage (Bolch et al., 2010;

627 Granshaw \& Fountain, 2006; Paul, 2004). The total area decreased by -45\% since 1980 at a rate 628 of $-1.3 \% \mathrm{yr}^{-1}$, faster than that for western Canada $-0.6 \% \mathrm{yr}^{-1}$ (1985-2000) (Bolch et al., 2010) and 629 faster than in the North Cascade Range $100 \mathrm{~km}$ to the northeast, $-0.4 \% \mathrm{yr}^{-1}$ (1959-2009) (Riedel 630 and Larrabee, 2016). However, as Bolch et al., (2010) point out this difference is probably due 631 to differences in glacier size because, as a general rule, smaller glaciers retreat faster than 632 larger glaciers. In addition, the glaciers in the Olympic Mountains are found at lower elevations 633 than most other regions. The retreat rate in the Olympics is more similar to the retreat rate of 634 small glaciers in western Canada such as on Vancouver Island $\left(-1.11 \% \mathrm{yr}^{-1}\right)$, the Central Coast (- 
$\left.6351.2 \% \mathrm{yr}^{-1}\right)$, or the Northern Interior $\left(-1.11 \% \mathrm{yr}^{-1}\right)$. Our rate is also faster than glaciers in the 636 Wind River Range, Wyoming, USA $\left(-0.65 \% \mathrm{yr}^{-1}, 1966-2006\right)$, or the European Alps $\left(-0.9 \% \mathrm{yr}^{-1}\right.$, $6371970-2003$ ) although Paul et al. (2011) argue for a rate of about $2 \% \mathrm{yr}^{-1}$ from the mid-1980's 638 to 2003. In any case, the rate of retreat is within the range of other published studies.

640 Examination of topographic influences on glacier shrinkage showed that elevation was the only 641 significant influence, similar to other studies (DeVisser \& Fountain, 2015). The scatter about the 642 regression line can be due to any number of factors including glacier hypsometry, aspect, and 643 slope (Fischer et al., 2015; Tangborn et al., 1990). A confounding factor is that smaller glaciers 644 generally retreat more than larger glaciers, and the retreat variability in much greater for 645 smaller glaciers (Figure 4; DeBEER \& Sharp, 2007; Granshaw \& Fountain, 2006; Paul, 2004). The 646 presence and change of small glaciers is highly dependent on the interrelation of topographic 647 and climatic factors (DeBEER \& Sharp, 2009; Kessler et al., 2006; Kuhn, 1995). The absence of 648 hypsometric influence on the magnitude of area change may be due to the relatively small 649 glaciers that do not span a large elevation range so the climate differs little between the 650 terminus and head of the glacier.

652 The rate of specific volume changes averaged $-0.46 \mathrm{~m} \mathrm{yr}^{-1}, 1980-2015$, and is comparable to the 653 mass change of the 30 global reference glaciers for the same time period (WGMS, 2019). Our 654 value is also close to that for the Olympic Mountains of $-0.55 \mathrm{~m} \mathrm{yr}^{-1}$ (2000-2015) estimated from 655 satellite imagery (Menounos et al., 2018) and to Riedel et al. (2015) of $-0.54 \mathrm{~m} \mathrm{yr}^{-1}$ (1980-2009) 656 based on aerial photographs. Using area-volume scaling, about $0.75 \pm 0.19 \mathrm{~km}^{3}$ of ice remains in 657 the Olympic Mountains as of 2015. Examining the changes on Mount Olympus, the largest 658 fraction of glacier-covered area is at $1750 \mathrm{~m}$, but the maximum fractional volume change 659 (1980-2015) occurs $150 \mathrm{~m}$ lower at $1600 \mathrm{~m}$ amsl. This is the cross-over point between 660 decreasing specific volume change with elevation and increasing glacier-covered area. Such an 661 elevation offset is probably not unusual. Abermann et al. (2009) found similar results in Austria 662 for area change. Specific volume change no longer decreases with elevation above $2000 \mathrm{~m}$, 663 becoming constant at -9 m. A similar result, -11 m (1985-1999), occurs for glaciers of British 
664 Columbia, Canada (Schiefer et al., 2007). A constant thinning with elevation seems to occur at 665 about 0.75 of the normalized elevation differences from the terminus to the glacier head in a 666 number of regions (Arendt et al., 2006; Schiefer et al., 2007). The constant thinning at the 667 upper-most elevations is similar to the constant mass balance at the upper-most elevations of 668 individual glaciers and not a unique finding (Dyurgerov et al., 2002). The effect of altitude on 669 ablation and accumulation can decrease significantly at high elevation due to cooler air 670 temperatures, snowfall may decrease with elevation due to limits on cloud elevation, and high 671 winds at elevation redistributes snow erasing an elevation dependence.

673 Based on the mass balance model of Blue Glacier, it is clear that variations in mass balance are 674 highly sensitive to variations in air temperature ( $83 \%$ of the variability) and less so to variations 675 in precipitation (53\%), given their low elevation and high mass turnover. This is a known 676 attribute of maritime glaciers (Anderson \& Mackintosh, 2012; Oerlemans \& Fortuin, 1992).

677 Overall the retreat of these glaciers is due to increasing air temperatures over the past century, 678 which has warmed by almost $1^{\circ} \mathrm{C}$ in winter, which can change the phase of precipitation from 679 snow to rain reducing mass accumulation and by about $+0.3^{\circ} \mathrm{C}$ in summer, which increases 680 melt. The Olympic Mountains have been identified as one of the regions within the Pacific 681 Northwest with warm snowpacks vulnerable to winter warming and increasing proportions of 682 winter rain rather than snow (Klos et al., 2014; Nolin \& Daly, 2006).

684 Of the climate indices correlated with monthly air temperatures and mass balance of Blue 685 Glacier and therefore the glaciers of the Olympic Mountains, the PNA and PDO patterns were 686 the strongest. PNA is a measure of the amplitude of the planetary wave field of atmospheric 687 heights (pressures) over the northeast Pacific and North America at intramonthly time scales. It 688 is correlated with freezing level in the atmosphere over western North America and most highly 689 correlated over coastal Oregon and Washington (Abatzoglous, 2011). The PNA documents 690 changes in atmospheric circulation, which contributes to wintertime warming and has been 691 shown to correlate with snowpack generally in the western US (Barnston \& Livezey, 1987; 692 Cayan, 1996; Gutzler \& Rosen, 1992). The impact of warming winter air temperatures on snow 
693 accumulation in the western US has been described generally (McCabe \& Wolock, 2009; Mote

694 et al., 2005, 2018) and specifically for Blue Glacier (Rasmussen \& Conway, 2000). Given that the

695 mass balance of Blue Glacier is highly sensitive to air temperature correlation with the PNA

696 index is not surprising. For PDO, the statistically significant correlation between temperature

697 and mass balance is also reflective of conditions in the North Pacific. The PDO, based on sea

698 surface temperatures, tends to vary over decadal time scales and is highly correlated with the

699 PNA (Mantua and Hare, 2002; Newman et al., 2016). Like the PNA, the PDO is also correlated

700 with snowpack variability such that positive PDO values, indicate warming along the coast of

701 the Pacific Northwest and warmer air temperatures and reduced snow accumulation in the

702 Pacific Northwest (McCabe \& Dettinger, 2002; Zhang et al., 2010). It is striking that the shifts in

703 the trend of mass balance of Blue Glacier are highly correlated with changes in the state of the

704 Pacific Ocean, which is related to the PDO. They also largely explain the variation in winter mass

705 accumulation estimated by Rasmussen \& Conway (2000). The 'warm' phases of the PDO, where

706 the ocean waters along the coast of western North America are warmer than normal, coincide

707 with periods of decreasing mass balance whereas 'cool' phases are associated with the glacier

708 mass balance in equilibrium or slightly gaining. This relationship has also been noted for Blue

709 Glacier by Malcomb and Wiles (2013).

710

711 The response of glacier mass balance to climate indices in the Pacific Northwest have been well

712 explored and show that the glacier mass balance is sensitive to conditions in the North Pacific

713 Ocean (Bitz \& Battisti, 1999; Hodge et al., 1998; Walters \& Meier, 1989). Using the measured

714 mass balance record from South Cascade Glacier, $150 \mathrm{~km}$ to the northeast of Blue Glacier in the

715 Cascade Mountains, McCabe and Fountain (1995) showed that variations in in annual mass

716 balance were driven by winter snow accumulation. From that Hodge et al., (1998) showed good

717 correlations between winter mass balance and PNA; Bitz and Battisti (1999) showed good

718 correlations with PDO and much less so with ENSO. McCabe and Fountain (1995) examined the

719 correlations between the $700 \mathrm{mb}$ atmospheric pressure field and the winter mass balance,

720 finding a correlative pressure pattern across western North America similar to the PNA.

721 Atmospheric circulation patterns that increase zonal westerly flow from the Pacific Ocean to 
722 the Pacific Northwest have been shown to increase precipitation, particularly in high alpine

723 terrain (Luce et al., 2013; Menounos et al., 2018; Shea \& Marshall, 2007). Increases in such

724 precipitation in winter, if air temperatures are below freezing, increase glacier mass balance.

725 However, increasingly warm winter climate since 2000 suggests that the cool phase of the PDO

726 is also becoming warmer reducing its ability to nourish the glaciers (Josberger et al., 2007).

727

728 The predicted demise of the glaciers by 2100 is not unique. Predictions of glacier change in 729 western Canada suggest a 70\% volume loss by 2100 but for the Coastal Mountains of the 730 Central Coast and Vancouver Island, complete loss on or before 2100 (Clarke et al., 2015) (see

731 also supplementary material). This supports prior work in along the eastern slopes of the

732 Canadian Rocky Mountains and for selected glacier-populated basins in the Pacific Northwest

733 that are predicted to lose $80-90 \%$ of the glacier volume by 2100 (Frans et al., 2018; Marshall et

734 al., 2011). Predictions of global alpine glacier change suggest rapid loss for the rest of the 735 century and for the region of western Canada and US, exclusive of Alaska, at least 50\% loss

736 (Radić \& Hock, 2011).

\section{Conclusions}

740 Careful updating of prior glacier inventories is required to avoid introducing error based on

741 methodological differences or different assumptions regarding glacier boundaries. Glacier by

742 glacier comparisons between inventories minimized such errors.

743 The initial inventory of glaciers in the Olympic Mountains showed that the total area in 1980

744 was $45.9 \pm 0.51 \mathrm{~km}^{2}$ with a mean glacier area of $0.18 \mathrm{~km}^{2}$. By 2015 the total area decreased -45

$745 \pm 0.02 \%$, mean glacier area decreased to $0.08 \mathrm{~km}^{2}$, and 35 glaciers and 16 perennial snowfields

746 disappeared. Over this period glacier area decreased at a rate of $-0.59 \mathrm{~km}^{2} \mathrm{yr}^{-1}$, with the fastest

747 rate during the 2009-2015 period, $-0.82 \pm 0.02 \mathrm{~km}^{2} \mathrm{yr}^{-1}$. Like other studies elsewhere, smaller

748 glaciers retreated more than larger glaciers, they also showed the most variability. The

749 variability is probably a result of favorable local conditions that decrease melt and increase

750 accumulation compared to less favorable conditions. To infer changes prior to 1980 we used 
751 Blue Glacier, the largest $\left(5.143 \pm 0.094 \mathrm{~km}^{2}\right.$ in 2015$)$ and most well documented glacier in the

752 region, as a proxy for regional glacier change because of its high correlation with the regional

753 area change. In 1900, the total area covered by glaciers was $55.3 \mathrm{~km}^{2}$ more than twice the area 754 in 2015.

755 A simple mass balance model of Blue Glacier, based on monthly air temperature and

756 precipitation, showed good correspondence with changes in glacier area. Interrogation of the

757 model showed that variations in monthly mass accumulation is better explained by variations in

758 air temperature than precipitation, suggesting the importance of temperature control on the

759 precipitation phase. Ablation is highly correlated with temperature alone. Taken together air

760 temperature is the dominant influence on glacier mass balance in the Olympic Mountains,

761 explaining $83 \%$ of the variance, with precipitation playing a secondary role. This is common to

762 glaciers in maritime climates where winter air temperatures are close to the $0^{\circ} \mathrm{C}$ threshold and

763 only a small change in temperature can change the phase of the precipitation from snow to

764 rain. The mass changes are highly correlated with the Pacific North American index, a measure

765 of the strength of zonal versus meridional air flow over North America at weekly-seasonal time

766 scales. The changes are also correlated with regime shifts of the Pacific Decadal Oscillation, a

767 measure of sea surface temperatures in the North Pacific that varies over decadal time scales.

768 Finally, the future of these glaciers is grim. Using a coupled global circulation model with a

769 distributed glacier flow model shows that the glaciers of the Olympic Mountains should largely

770 disappear by 2070.

\section{Acknowledgements}

772 Supplementary Online Data can be found at, https://doi.org/10.15760/geology-data.02 The

773 authors wish to acknowledge Steve Wilson who collected some of the early data and to Greg

774 McCabe who provided very helpful comments on the climate section. This work was funded by

775 the US Geological Survey via the Western Mountain Initiative.

\section{Author Contributions}

778 Andrew G. Fountain identified the goals and aims of the project, and participating in all phases

779 of analysis and wrote the paper. Christina Gray applied the regional glaciation model to the 
780 Olympic Mountains and edited the paper. Bryce Glenn created the 2015 glacier inventory and

781 did the GIS analysis of glacier change, topography and climate across the region. Brian

782 Menounos adapted the original formulation of regional glaciation model to include paleo GCM

783 input, helped with preparing datasets for model inclusion, advised Christina on model

784 implementation, and helped with the editing. Justin Pflug supplied the 2015 DEM data used for

785 estimating glacier volume change and helped edit the paper. Jon Riedel supplied some of the

786 glacier area data prior to 2015 and helped edit the paper.

787

788 


\section{References}

Abermann, J., Lambrecht, A., Fischer, A., \& Kuhn, M. (2009). Quantifying changes and trends in glacier area and volume in the Austrian Ötztal Alps (1969-1997-2006). The Cryosphere Discussions, 3(2), 415-441. https://doi.org/10.5194/tc-3-205-2009

Abatzoglou, J. T. (2011). Influence of the PNA on declining mountain snowpack in the Western United States. International Journal of Climatology, 31(8), 1135-1142. https://doi.org/10.1002/joc.2137

AGS. (1960). Nine Glacier Maps, Northwestern North America: Accompanied by Nine Separate Map Sheets on Scale of 1: 10,000. American Geographical Society, Vol. 34, Lane Press.

Anderson, B., \& Mackintosh, A. (2012). Controls on mass balance sensitivity of maritime glaciers in the Southern Alps, New Zealand: The role of debris cover. Journal of Geophysical Research, 117(F1). https://doi.org/10.1029/2011JF002064

Arendt, A., Echelmeyer, K., Harrison, W., Lingle, C., Zirnheld, S., Valentine, V., Ritchie, B., \& Druckenmiller, M. (2006). Updated estimates of glacier volume changes in the western Chugach Mountains, Alaska, and a comparison of regional extrapolation methods. Journal of Geophysical Research, 111(F3). https://doi.org/10.1029/2005JF000436

Armstrong, R. L. (1989). Mass balance history of Blue Glacier, Washington, USA. In J. Oerlemans (Ed.), Glacier Fluctuations and Climatic Change (pp. 183-192). Springer Netherlands.

Bahr, D. B., Pfeffer, W. T., \& Kaser, G. (2015). A review of volume-area scaling of glaciers: Volume-Area Scaling. Reviews of Geophysics, 53(1), 95-140. https://doi.org/10.1002/2014RG000470 
811 Baird, D. C. (1962). Experimentation: An introduction to measurement theory and experiment design. Prentice Hall. https://doi.org/0-13-295345-5

813 Barnston, A. G., \& Livezey, R. E. (1987). Classification, seasonality and persistence of low-

814 frequency atmospheric circulation patterns. Monthly Weather Review, 115(6), 10831126. https://doi.org/10.1175/1520-0493(1987)115<1083:CSAPOL>2.0.CO;2

Basagic, H. J., \& Fountain, A. G. (2011). Quantifying 20th Century Glacier Change in the Sierra Nevada, California. Arctic, Antarctic, and Alpine Research, 43(3), 317-330.

Bitz, C. M., \& Battisti, D. S. (1999). Interannual to Decadal Variability in Climate and the Glacier Mass Balance in Washington, Western Canada, and Alaska. Journal of Climate, 12(11),

822 Bjerknes, J. (1966). A possible response of the atmospheric Hadley circulation to equatorial anomalies of ocean temperature. Tellus, 18(4), 820-829.

Bolch, T., Menounos, B., \& Wheate, R. (2010). Landsat-based inventory of glaciers in western https://doi.org/10.1016/j.rse.2009.08.015

830 Cayan, D. R. (1996). Interannual Climate Variability and Snowpack in the Western United States. Journal of Climate, 9(5), 928-948. https://doi.org/10.1175/1520- 
833 Chen, J., \& Ohmura, A. (1990). Estimation of Alpine glacier water resources and their change since the 1870s. IAHS Publ, 193, 127-135.

Chen, W. (1982). Assessment of Southern Oscillation sea-level pressure indices. Monthly Weather Review, 110(7), 800-807. https://doi.org/10.1175/15200493(1982)110<0800:AOSOSL>2.0.CO;2

Clarke, G. K. C., Jarosch, A. H., Anslow, F. S., Radić, V., \& Menounos, B. (2015). Projected

Clow, D. W., \& Sueker, J. K. (2000). Relations between basin characteristics and stream water chemistry in alpine/subalpine basins in Rocky Mountain National Park, Colorado. Water

Conway, H., Rasmussen, L. A., \& Marshall, H. P. (1999). Annual mass balance of Blue Glacier, USA: 1955-97. Geografiska Annaler: Series A, Physical Geography, 81(4), 509-520.

Cuffey, K. M., \& Paterson, W. S. B. (2010). The Physics of Glaciers (4th ed.). Academic Press.

Daly, C., Smith, J. W., Smith, J. I., \& McKane, R. B. (2007). High-Resolution Spatial Modeling of https://doi.org/10.1111/1468-0459.00080

DeBEER, C. M., \& Sharp, M. J. (2007). Recent changes in glacier area and volume within the southern Canadian Cordillera. Annals of Glaciology, 46(1), 215-221. https://doi.org/10.3189/172756407782871710 
855 DeBEER, C. M., \& Sharp, M. J. (2009). Topographic influences on recent changes of very small glaciers in the Monashee Mountains, British Columbia, Canada. Journal of Glaciology, 55(192), 691-700. https://doi.org/10.3189/002214309789470851

858

DeVisser, M. H., \& Fountain, A. G. (2015). A century of glacier change in the Wind River Range, WY. Geomorphology, 232, 103-116. https://doi.org/10.1016/j.geomorph.2014.10.017

Dyurgerov, M., Meier, M., \& Armstrong, R. L. (2002). Glacier mass balance and regime: Data of measurements and analysis. Institute of Arctic and Alpine Research, University of

871 Fischer, M., Huss, M., \& Hoelzle, M. (2015). Surface elevation and mass changes of all Swiss glaciers 1980-2010. The Cryosphere, 9(2), 525-540. https://doi.org/10.5194/tc-9-525-

874 Fischer, Mauro, Huss, M., Barboux, C., \& Hoelzle, M. (2014). The New Swiss Glacier Inventory SGI2010: Relevance of Using High-Resolution Source Data in Areas Dominated by Very 
Small Glaciers. Arctic, Antarctic, and Alpine Research, 46(4), 933-945.

878 Fountain, A. G., Glenn, B., \& Basagic, H. J. (2017). The Geography of Glaciers and Perennial Snowfields in the American West. Arctic, Antarctic, and Alpine Research, 49(3), 391-410.

Fountain, A. G., Hoffman, M. J., Jackson, K., Basagic, H. J., Nylen, T. H., \& Percy, D. (2007). Digital outlines and the topography of the Glaciers of the American West (Open File Report No. 2006-1340; p. 23). US Geological Survey.

\section{5} https://doi.org/10.1657/AAAR0017-003 https://doi.org/10.3133/ofr20061340

Frans, C., Istanbulluoglu, E., Lettenmaier, D. P., Fountain, A. G., \& Riedel, J. (2018). Glacier Recession and the Response of Summer Streamflow in the Pacific Northwest United States, 1960-2099. Water Resources Research. https://doi.org/10.1029/2017WR021764

Gedalof, Z., \& Smith, D. J. (2001). Interdecadal climate variability and regime-scale shifts in Pacific North America. Geophysical Research Letters, 28(8), 1515-1518. https://doi.org/10.1029/2000GL011779

Gent, P. R., Danabasoglu, G., Donner, L. J., Holland, M. M., Hunke, E. C., Jayne, S. R., Lawrence, D. M., Neale, R. B., Rasch, P. J., \& Vertenstein, M. (2011). The community climate system model version 4. Journal of Climate, 24(19), 4973-4991. https://doi.org/10.1175/2011JCLI4083.1

Gesch, D., Oimoen, M., Greenlee, S., Nelson, C., Steuck, M., \& Tyler, D. (2002). The national elevation dataset. Photogrammetric Engineering and Remote Sensing, 68(1), 5-32. 
Ghilani, C. D. (2000). Demystifying area uncertainty: More or less. Surveying and Land Information Systems, 60(3), 177-182.

Gorelick, N., Hancher, M., Dixon, M., Ilyushchenko, S., Thau, D., \& Moore, R. (2017). Google Earth Engine: Planetary-scale geospatial analysis for everyone. Remote Sensing of Environment, 202, 18-27. https://doi.org/10.1016/j.rse.2017.06.031

Granshaw, F. D., \& Fountain, A. G. (2006). Glacier change (1958-1998) in the North Cascades National Park Complex, Washington, USA. Journal of Glaciology, 52(177), 251-256.

Gutmann, E. D., Rasmussen, R. M., Liu, C., Ikeda, K., Gochis, D. J., Clark, M. P., Dudhia, J., \& Thompson, G. (2012). A comparison of statistical and dynamical downscaling of winter https://doi.org/10.1175/2011JCLI4109.1

Gutzler, D. S., \& Rosen, R. D. (1992). Interannual Variability of Wintertime Snow Cover across and 1989. Progress in Oceanography, 47(2-4), 103-145. https://doi.org/10.1016/S0079-

915 Hodge, S. M., Trabant, D. C., Krimmel, R. M., Heinrichs, T. A., March, R. S., \& Josberger, E. G. (1998). Climate variations and changes in mass of three glaciers in western North 6611(00)00033-1 (1998). Climate variations and changes in mass of three glaciers in western North America. Journal of Climate, 11(9), 2161-2179. https://doi.org/10.1175/15200442(1998)011<2161:CVACIM>2.0.CO;2 
919 Hoffman, M. J., Fountain, A. G., \& Achuff, J. M. (2007). 20th-century variations in area of cirque 920 glaciers and glacierets, Rocky Mountain National Park, Rocky Mountains, Colorado, USA. $921 \quad$ Annals of Glaciology, 46(1), 349-354. https://doi.org/10.3189/172756407782871233

922 Huss, M., \& Farinotti, D. (2012). Distributed ice thickness and volume of all glaciers around the 923 globe. Journal of Geophysical Research, 117(F4). https://doi.org/10.1029/2012JF002523

924 Jiskoot, H., Curran, C. J., Tessler, D. L., \& Shenton, L. R. (2009). Changes in Clemenceau Icefield 925 and Chaba Group glaciers, Canada, related to hypsometry, tributary detachment, 926 length-slope and area-aspect relations. Annals of Glaciology, 50(53), 133-143. ). 927 https://doi.org/10.3189/172756410790595796

928 Jo, H.-S., Yeh, S.-W., \& Lee, S.-K. (2015). Changes in the relationship in the SST variability 929 between the tropical Pacific and the North Pacific across the 1998/1999 regime shift. $930 \quad$ Geophysical Research Letters, 42(17), 7171-7178.

$931 \quad$ https://doi.org/10.1002/2015GL065049

932 Jones, P. D., Jonsson, T., \& Wheeler, D. (1997). Extension to the North Atlantic Oscillation using 933 early instrumental pressure observations from Gibraltar and South-west Iceland. 934 International Journal of Climatology, 17, 1433-1450.

935 https://doi.org/10.1002/(SICI)1097-0088(19971115)17:13<1433::AID-JOC203>3.0.CO;2$936 \quad P$

937 Josberger, E. G., Bidlake, W. R., March, R. S., \& Kennedy, B. W. (2007). Glacier mass-balance 938 fluctuations in the Pacific Northwest and Alaska, USA. Annals of Glaciology, 46, 291939 296. https://doi.org/10.3189/172756407782871314 
940 Kessler, M. A., Anderson, R. S., \& Stock, G. M. (2006). Modeling topographic and climatic

941

942

943

944

945

946

947

948

949

950

951

952

953

954

955

956

957

958

959

960 control of east-west asymmetry in Sierra Nevada glacier length during the Last Glacial Maximum. Journal of Geophysical Research, 111(F2). https://doi.org/10.1029/2005JF000365

Klos, P. Z., Link, T. E., \& Abatzoglou, J. T. (2014). Extent of the rain-snow transition zone in the western U.S. under historic and projected climate: Climatic rain-snow transition zone. Geophysical Research Letters, 41(13), 4560-4568.

https://doi.org/10.1002/2014GL060500

Kuhn, M. (1995). The mass balance of very small glaciers. Zeitschrift Fur Gletscherkunde Und Glazialgeologie, 5, 171-179.

LaChapelle, E. (1959). Annual mass and energy exchange on the Blue Glacier. Journal of Geophysical Research, 64(4), 443-449. https://doi.org/10.1029/JZ064i004p00443

LaChapelle, Edward. (1965). Mass Budget of Blue Glacier, Washington. Journal of Glaciology, 5(41), 609-623. https://doi.org/10.3189/\$0022143000018633

Litzow, M. A., \& Mueter, F. J. (2014). Assessing the ecological importance of climate regime shifts: An approach from the North Pacific Ocean. Progress in Oceanography, 120, 110119. https://doi.org/10.1016/j.pocean.2013.08.003

Livneh, B., Deems, J. S., Schneider, D., Barsugli, J. J., \& Molotch, N. P. (2014). Filling in the gaps: Inferring spatially distributed precipitation from gauge observations over complex terrain. Water Resources Research, 50(11), 8589-8610.

https://doi.org/10.1002/2014WR015442 
961 Luce, C. H., Abatzoglou, J. T., \& Holden, Z. A. (2013). The Missing Mountain Water: Slower Westerlies Decrease Orographic Enhancement in the Pacific Northwest USA. Science, 342(6164), 1360-1364. https://doi.org/10.1126/science.1242335

964 Malcomb, N. L., \& Wiles, G. C. (2013). Tree-ring-based reconstructions of North American glacier mass balance through the Little Ice Age-Contemporary warming transition. Quaternary Research, 79(2), 123-137. https://doi.org/10.1016/j.yqres.2012.11.005

Mantua, N. J., \& Hare, S. R. (2002). The Pacific decadal oscillation. Journal of Oceanography, 58(1), 35-44. https://doi.org/10.1023/A:1015820616384

Marshall, S. J., White, E. C., Demuth, M. N., Bolch, T., Wheate, R., Menounos, B., Beedle, M. J., \& Shea, J. M. (2011). Glacier Water Resources on the Eastern Slopes of the Canadian

973 McCabe, G. J., \& Dettinger, M. D. (2002). Primary modes and predictability of year-to-year snowpack variations in the western United States from teleconnections with Pacific Ocean climate. Journal of Hydrometeorology, 3(1), 13-25.

977 McCabe, G. J., \& Fountain, A. G. (1995). Relations between atmospheric circulation and mass balance of South Cascade Glacier, Washington, USA. Arctic and Alpine Research, 27(3),

980 McCabe, G. J., \& Fountain, A. G. (2013). Glacier variability in the conterminous United States during the twentieth century. Climatic Change, 116(3-4), 565-577. 
983 McCabe, G. J., \& Wolock, D. M. (2009). Recent Declines in Western U.S. Snowpack in the Context of Twentieth-Century Climate Variability. Earth Interactions, 13(12), 1-15. https://doi.org/10.1175/2009EI283.1

Menounos, B., Hugonnet, R., Shean, D., Gardner, A., Howat, I., Berthier, E., Pelto, B., Tennant, C., Shea, J., Noh, M., Brun, F., \& Dehecq, A. (2018). Heterogeneous changes in western North American glaciers linked to decadal variability in zonal wind strength. Geophysical Research Letters. https://doi.org/10.1029/2018GL080942

Minobe, S. (2002). Interannual to interdecadal changes in the Bering Sea and concurrent 1998/99 changes over the North Pacific. Progress in Oceanography, 55(1-2), 45-64. https://doi.org/10.1016/S0079-6611(02)00069-1

Mote, P. W., Hamlet, A. F., Clark, M. P., \& Lettenmaier, D. P. (2005). Declining mountain snowpack in western North America. Bulletin of the American Meteorological Society,

996 Mote, P. W., Li, S., Lettenmaier, D. P., Xiao, M., \& Engel, R. (2018). Dramatic declines in snowpack in the western US. Climate and Atmospheric Science, 1(1). https://doi.org/10.1038/s41612-018-0012-1

999 Newman, M., Alexander, M. A., Ault, T. R., Cobb, K. M., Deser, C., Di Lorenzo, E., Mantua, N. J., Miller, A. J., Minobe, S., \& Nakamura, H. (2016). The Pacific decadal oscillation, revisited.

1002 NOAA (2018). www.esrl.noaa.gov/psd/gcos_wgsp/Timeseries/ Accessed, August 2018

1003 Nolin, A. W., \& Daly, C. (2006). Mapping "at risk" snow in the Pacific Northwest. Journal of 1004 Hydrometeorology, 7(5), 1164-1171. https://doi.org/10.1175/JHM543.1 
1005 Oerlemans, J., \& Fortuin, J. (1992). Sensitivity of glaciers and small ice caps to greenhouse

1006 warming. Science, 258(5079), 115-117. https://doi.org/10.1126/science.258.5079.115

1007

1008

1009

1010

1011

1012

1013

1014

1015

1016

1017

1018

1019

1020

1021

1022

1023

1024

1025

OSU, 2017. www.prism.oregonstate.edu, accessed November 2017.

Overland, J., Rodionov, S., Minobe, S., \& Bond, N. (2008). North Pacific regime shifts:

Definitions, issues and recent transitions. Progress in Oceanography, 77(2-3), 92-102. https://doi.org/10.1016/j.pocean.2008.03.016

Painter, T. H., Berisford, D. F., Boardman, J. W., Bormann, K. J., Deems, J. S., Gehrke, F., Hedrick, A., Joyce, M., Laidlaw, R., Marks, D., Mattmann, C., McGurk, B., Ramirez, P., Richardson, M., Skiles, S. M., Seidel, F. C., \& Winstral, A. (2016). The Airborne Snow Observatory: Fusion of scanning lidar, imaging spectrometer, and physically-based modeling for mapping snow water equivalent and snow albedo. Remote Sensing of Environment, 184, 139-152. https://doi.org/10.1016/j.rse.2016.06.018

Paul, F., Frey, H., \& Le Bris, R. (2011). A new glacier inventory for the European Alps from Landsat TM scenes of 2003: Challenges and results. Annals of Glaciology, 52(59), 144152. https://doi.org/10.3189/172756411799096295

Paul, F. (2004). Rapid disintegration of Alpine glaciers observed with satellite data. Geophysical Research Letters, 31(21). https://doi.org/10.1029/2004GL020816

Paul, F., Barry, R. G., Cogley, J. G., Frey, H., Haeberli, W., Ohmura, A., Ommnney, C. S. L., Raup, B., Rivera, A., \& Zemp, M. (2010). Guidelines for the compilation of glacier inventory data from digital sources. Annals of Glaciology, 50(53), 119-126. https://doi.org/10.3189/172756410790595778 
1026 Pfeffer, W. T., Arendt, A. A., Bliss, A., Bolch, T., Cogley, J. G., Gardner, A. S., Hagen, J.-O., Hock,

1027

1028

1029

1030

1031

1032

1033

1034

1035

1036

1037

1038

1039

1040

1041

1042

1043

1044

1045

R., Kaser, G., \& Kienholz, C. (2014). The Randolph Glacier Inventory: A globally complete inventory of glaciers. Journal of Glaciology, 60(221), 537-552.

https://doi.org/10.3189/2014JoG13J176

Radić, V., \& Hock, R. (2011). Regionally differentiated contribution of mountain glaciers and ice caps to future sea-level rise. Nature Geoscience, 4(2), 91-94.

https://doi.org/10.1038/ngeo1052

Rasmussen, L. A., Conway, H., \& Hayes, P. S. (2000). The accumulation regime of Blue Glacier, USA, 1914-96. Journal of Glaciology, 46(153), 326-334.

https://doi.org/10.3189/172756500781832846

Rayner, N., Parker, D. E., Horton, E., Folland, C., Alexander, L., Rowell, D., Kent, E., \& Kaplan, A. (2003). Global analyses of sea surface temperature, sea ice, and night marine air temperature since the late nineteenth century. Journal of Geophysical Research: Atmospheres, 108(D14), 2156-2202. https://doi.org/10.1029/2002JD002670

Riedel, Jon L., \& Larrabee, M. A. (2016). Impact of Recent Glacial Recession on Summer Streamflow in the Skagit River. Northwest Science, 90(1), 5-22. https://doi.org/10.3955/046.090.0103

Riedel, Jon L., Wilson, S., Baccus, W., Larrabee, M., Fudge, T. J., \& Fountain, A. (2015). Glacier status and contribution to streamflow in the Olympic Mountains, Washington, USA. Journal of Glaciology, 61(225), 8-16. https://doi.org/10.3189/2015JoG14J138 
1046 Riedel, Jon L., \& Larrabee, M. A. (2016). Impact of Recent Glacial Recession on Summer

1047 Streamflow in the Skagit River. Northwest Science, 90(1), 5-22.

$1048 \quad$ https://doi.org/10.3955/046.090.0103

1049 Ropelewski, C. F., \& Jones, P. D. (1987). An extension of the Tahiti-Darwin southern oscillation $1050 \quad$ index. Monthly Weather Review, 115(9), 2161-2165.

1051 Schiefer, E., Menounos, B., \& Wheate, R. (2007). Recent volume loss of British Columbian 1052 glaciers, Canada: Volume loss of BC glaciers. Geophysical Research Letters, 34(16), 1053 L16503. https://doi.org/10.1029/2007GL030780

1054 Shea, J. M., \& Marshall, S. J. (2007). Atmospheric flow indices, regional climate, and Glacier 1055 mass balance in the Canadian Rocky Mountains. International Journal of Climatology,

Spicer, R. (1986). Glaciers in the Olympic Mountains, Washington-Present distribution and 27(2), 233-247. https://doi.org/10.1002/joc.1398 recent variations. [M.S.]. University of Washington.

Spicer, R. C. (1989). Recent variations of Blue Glacier, Olympic Mountains, Washington, USA.

1061 Tangborn, W. V., Fountain, A. G., \& Sikonia, W. G. (1990). Effect of area distribution with altitude on glacier mass balance-a comparison of North and South Klawatti Glaciers,

1064 Thompson, D. W. J., \& Wallace, J. M. (1998). The Arctic oscillation signature in the wintertime 1065 geopotential height and temperature fields. Geophysical Research Letters, 25(9), 12971300. https://doi.org/10.1029/98GL00950 
1067 Thompson, D. W. J., Wallace, J. M., Kennedy, J. J., \& Jones, P. D. (2010). An abrupt drop in

1068

1069

1070

1071

1072

1073

1074

1075

1076

1077

1078

1079

1080

1081

1082

1083

1084

1085

1086

1087

1088

Northern Hemisphere sea surface temperature around 1970. Nature, 467(7314), 444447. https://doi.org/10.1038/nature09394

Trenberth, K. E. (1997). The definition of el nino. Bulletin of the American Meteorological Society, 78(12), 2771-2778. https://doi.org/10.1175/1520-

0477(1997)078<2771:TDOENO>2.0.CO;2

Trenberth, K. E., \& Hurrell, J. W. (1994). Decadal atmosphere-ocean variations in the Pacific.

Climate Dynamics, 9(6), 303-319. https://doi.org/10.1007/BF00204745

USDA, 2019. https://www.fsa.usda.gov/programs-and-services/aerial-photography/imagery-

programs/naip-imagery/index, accessed March 2017

UW, 2019. http://gis.ess.washington.edu/data/raster/doqs/index.html, data referenced November 2007

UW, (2018). research.jisao.washington.edu/datasets/pdo/

Van Vuuren, D. P., Edmonds, J., Kainuma, M., Riahi, K., Thomson, A., Hibbard, K., Hurtt, G. C., Kram, T., Krey, V., \& Lamarque, J.-F. (2011). The representative concentration pathways: An overview. Climatic Change, 109(1-2), 5. https://doi.org/10.1007/s10584-011-0148-z

Wallace, J. M., \& Gutzler, D. S. (1981). Teleconnections in the Geopotential Height Field during the Northern Hemisphere Winter. Monthly Weather Review, 109(4), 784-812. https://doi.org/10.1175/1520-0493(1981)109<0784:TITGHF>2.0.CO;2

Walters, R. A., \& Meier, M. F. (1989). Variability of Glacier Mass Balances in Western North America. In Aspects of Climate Variability in the Pacific and the Western Americas (pp. 365-374). American Geophysical Union. http://dx.doi.org/10.1029/GM055p0365 
1089 WGMS, 2019, https://wgms.ch/faqs/ data referenced, February 2019.

1090

1091 Wood, R. L. (1976). Men, mules, and mountains: Lieutenant O'Neil's Olympic expeditions.

$1092 \quad$ Mountaineers Books.

1093 Zhang, X., Wang, J., Zwiers, F. W., \& Groisman, P. Y. (2010). The influence of large-scale climate

1094 variability on winter maximum daily precipitation over North America. Journal of

1095 Climate, 23(11), 2902-2915. https://doi.org/10.1175/2010JCLI3249.1

1096

1097 


\section{Appendix}

Uncertainty Assessment of the interpretation uncertainty evolved over time. For the 1990 imagery we followed Spicer (1986) whereby it was visually ranked into three categories: 1) excellent - minimal snow/rock cover or shadows, $\pm 2.5 \%$; 2) good - moderate cover or shadows, $\pm 7.5 \%$; and 3) poor - extensive cover or shadow $\pm 20 \%$. For the 2009 inventory, each glacier was outlined twice. The first outline included only clean and debris-covered ice as indicated by crevasses. The second outline included exposed ice, debris, and seasonal snow. The interpretation uncertainty is one-half of the difference between the two areas outlined. Although more precise, results did not vary significantly from a broader calibrated assessment we applied to the 2015 inventory. The glaciers were visually grouped into two categories low and high uncertainty. A subset of 37 (low) and 34 (high) glaciers were than outlined using the $\mathrm{min} / \mathrm{max}$ method. The difference between the minimum and maximum outline was then normalized to the glacier area and an average was calculated for the two groups. The low category had $\mathrm{a} \pm 4 \%$ uncertainty, and the high had $\pm 16 \%$ uncertainty.

Table A1. Comparison of the topographic characteristics for the most and least changed glaciers from the quartile analysis. Elev is elevation, Asp - aspect, Win winter, Sum - summer, Ann - annual, Temp - air temperature, Precip-precipitation Long - longitude, Lat - latitude, Frac Chg - fractional area change From: OlympicWilson-ReAnalysis/Quartile

\begin{tabular}{lrrrrr} 
& \multicolumn{1}{l}{$\begin{array}{l}\text { Largest } \\
\text { fractional } \\
\text { change }\end{array}$} & $\begin{array}{l}\text { Standard } \\
\text { deviation }\end{array}$ & $\begin{array}{l}\text { Least } \\
\text { fractional } \\
\text { change }\end{array}$ & $\begin{array}{l}\text { Standard } \\
\text { deviation }\end{array}$ & \multicolumn{2}{c}{$\begin{array}{l}\text { Upper minus } \\
\text { lower }\end{array}$} \\
\hline Mean Slope & 21 & 5 & 23 & 6 & -3 \\
Mean Elev & 1612 & 149 & 1764 & 124 & -152 \\
Max Elev & 1672 & 159 & 1923 & 183 & -250 \\
Min Elev & 1566 & 158 & 1598 & 181 & -32 \\
Mean Asp & 207 & 157 & 211 & 144 & -5 \\
Win Precip & 2697 & 1019 & 2655 & 1035 & 42 \\
Win Temp & -1.7 & 0.9 & -2.4 & 0.9 & 0.7 \\
Sum Temp & 9.3 & 0.8 & 8.7 & 0.8 & 0.6 \\
Ann. Precip & 3730 & 1429 & 3622 & 1482 & 108 \\
Ann Temp & 2.8 & 0.8 & 2.2 & 0.8 & 1 \\
Mean Long & -123.6 & 0.2 & -123 & 0.2 & -0.1 \\
Mean Lat & 47.8 & 0.1 & 48 & 0.1 & 0.0 \\
Mean Area & 0.06 & 0.09 & 0.56 & 1.19 & -0.50 \\
Mean Frac Chg & -0.98 & 0.03 & -0.37 & 0.12 & -0.61 \\
Number & 54 & & 55 & &
\end{tabular}


1121 Table A2. The area $\left(\mathrm{km}^{2}\right)$ of Blue Glacier used for the mass balance model. The area for the 1122 years 1915 - 1982 were from Spicer (1989). The area for 1990 - 2015 came from our analysis.

1123 The area is that of the trunk glacier and does not include the 'snow dome' which did not change 1124 in area over the time observed.

1125

\begin{tabular}{cc} 
Year & Area \\
\hline 1815 & 5.98 \\
1900 & 5.61 \\
1906 & 5.61 \\
1912 & 5.61 \\
1913 & 5.61 \\
1915 & 5.61 \\
1919 & 5.61 \\
1924 & 5.57 \\
1933 & 5.38 \\
1939 & 5.31 \\
1952 & 5.21 \\
1957 & 5.23 \\
1964 & 5.22 \\
1965 & 5.22 \\
1966 & 5.23 \\
1967 & 5.23 \\
1968 & 5.23 \\
1970 & 5.24 \\
1976 & 5.30 \\
1977 & 5.30 \\
1978 & 5.30 \\
1979 & 5.31 \\
1981 & 5.31 \\
1982 & 5.30 \\
1990 & 5.08 \\
2009 & 4.71 \\
2015 & 4.47 \\
& \\
\hline
\end{tabular}

1126

1127

1128

1129

1130

1131

1132

1133

1134 
1135 of the Pacific Ocean, PDO - Pacific decadal oscillation, PNA - Pacific North America, SOI 1136 Southern oscillation index, NP - North Pacific. See text for citations and data sources.

1137

\begin{tabular}{|c|c|c|c|c|c|c|c|c|c|c|}
\hline & ppt & temp & $M B$ & $\begin{array}{l}\text { Nino } \\
3.4\end{array}$ & PDO & PNA & SOI & $N P$ & $N A O$ & Sunspots \\
\hline ppt & 1.00 & & & & & & & & & \\
\hline temp & -0.12 & 1.00 & & & & & & & & \\
\hline $\mathrm{MB}$ & 0.52 & -0.74 & 1.00 & & & & & & & \\
\hline Nino 3.4 & -0.13 & 0.52 & -0.43 & 1.00 & & & & & & \\
\hline PDO & -0.19 & 0.53 & -0.52 & 0.55 & 1.00 & & & & & \\
\hline PNA & -0.11 & 0.64 & -0.59 & 0.53 & 0.66 & 1.00 & & & & \\
\hline SOI & 0.15 & -0.47 & 0.40 & -0.83 & -0.54 & -0.47 & 1.00 & & & \\
\hline NP & 0.15 & -0.58 & 0.56 & -0.45 & -0.58 & -0.71 & 0.48 & 1.00 & & \\
\hline NAO & 0.08 & 0.05 & 0.05 & 0.04 & 0.01 & -0.15 & -0.11 & 0.18 & 1.00 & \\
\hline Sunspots & -0.04 & 0.09 & -0.11 & 0.03 & -0.06 & -0.08 & 0.01 & -0.05 & 0.15 & 1.00 \\
\hline
\end{tabular}

1138

1139

1140

1141

1142

1143

1144

1145 


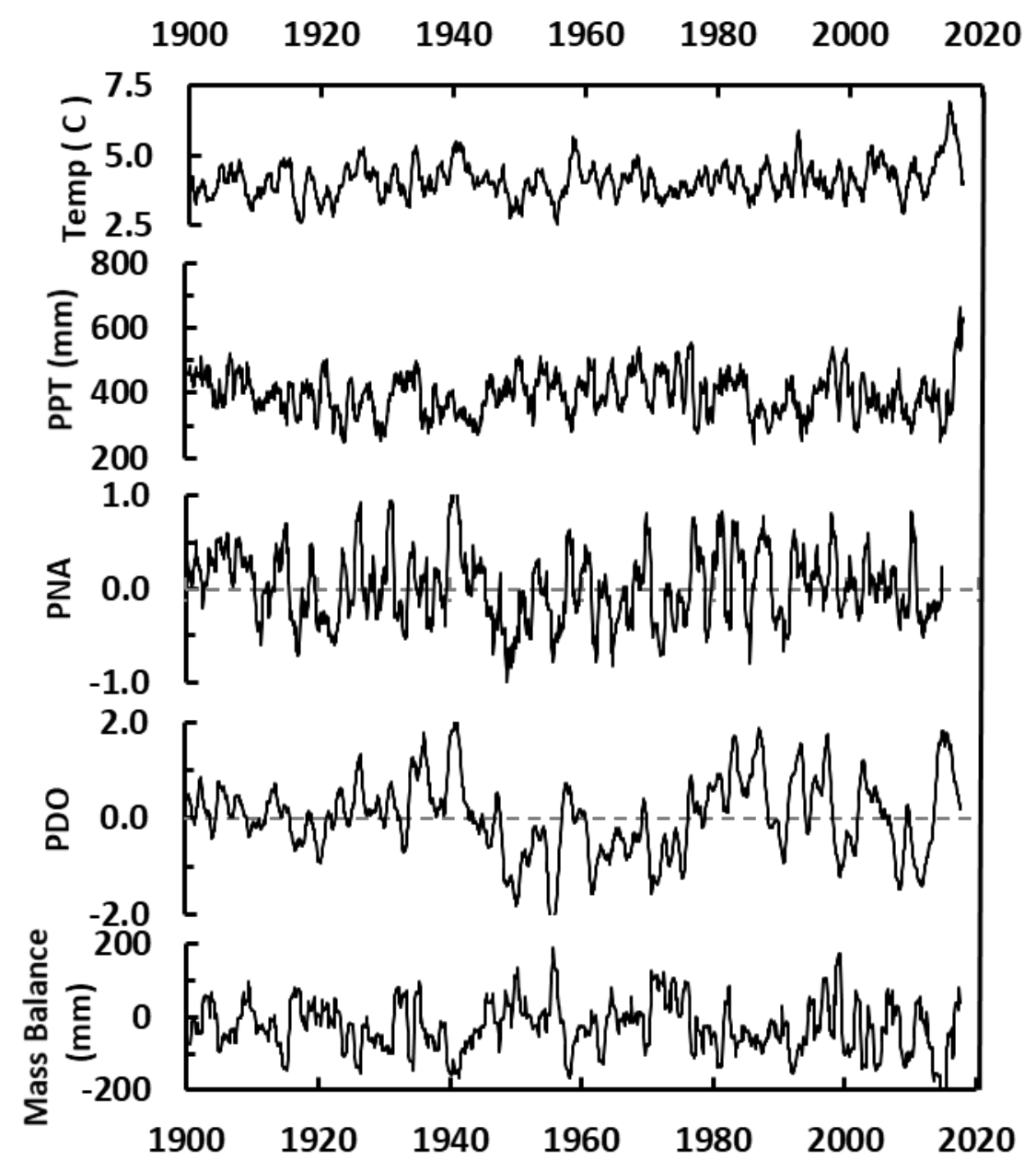

1148 Figure A1. Smoothed time series (1 year) of monthly local air temperature, precipitation, two 1149 climate idiocies (PNA - Pacific North America; PDO - Pacific Decadal Oscillation) and modeled 1150 glacier mass balance. 